\title{
Regulatory Arbitrage and International Bank Flows*
}

\author{
Joel F. Houston, Chen Lin, Yue Ma
}

August 26, 2011

Forthcoming, Journal of Finance

\begin{abstract}
We study whether cross-country differences in regulations have affected international bank flows. We find strong evidence that banks have transferred funds to markets with fewer regulations. This form of regulatory arbitrage suggests there may be a destructive "race to the bottom" in global regulations which restricts domestic regulators' ability to limit bank risk-taking. However, we also find that the links between regulation differences and bank flows are significantly stronger if the recipient country is a developed country with strong property rights and creditor rights. This suggests that while differences in regulations have important influences, that without a strong institutional environment, lax regulations are not enough to encourage massive capital flows.
\end{abstract}

\footnotetext{
* Contact Information: Joel F. Houston, Department of Finance Insurance \& Real Estate, Warrington College of Business Administration, University of Florida, PO BOX 117168, Gainesville, FL 32611-7168. (352) 302-7546, Houston@ufl.edu; Chen Lin, Department of Finance, Chinese University of Hong Kong, chenlin@cuhk.edu.hk; Yue Ma, Department of Economics, Lingnan University, Hong Kong, yuema@ln.edu.hk.
}

We thank Campbell Harvey (the editor), an associate editor and the referee for their very constructive and helpful comments. We thank Thorsten Beck, Daniel Berkowitz, David Brown, Charles Calomiris, Murillo Campello, Olivier De Jonghe, Avinash Dixit, Andrew Filardo, Mark Flannery, Borja Larrain, Micah Officer, Frank Packer, Eswar Prasad, Jun Qian, Mike Ryngaert, Frank Song, Yihui Wang, Yuhai Xuan, Bernard Yeung, Haibin Zhu and participants of 2009 ICCFFI conference in Hong Kong, 2010 Asian Development Bank Institute-China Banking Regulatory Commission-IMF conference on Banking Regulation and Financial Stability in Beijing and seminar participants at Chinese University of Hong Kong, National University of Singapore, Peking University, Tsinghua University and Tulane University for helpful comments. We also thank Philip Wooldridge from the BIS for clarifying some important conceptual issues of the BIS data and offering useful comments on our research. 


\section{Introduction}

The rapid increase in international banking and financial flows represents one of the most remarkable developments in the world economy over the past decade. According to statistics from the Bank for International Settlements (BIS), ${ }^{1}$ international banks' foreign claims increased from 1.12 trillion dollars in 1987 to 34 trillion dollars in 2007, suggesting that the international banking system is becoming a more important conduit for the transfer of capital across countries (McGuire and Tarashev, 2008).

Despite the large level of international bank flows, and despite recent attempts to increase the global coordination of bank regulation, much of the bank regulation and supervision remains national. Given this environment, it is reasonable to presume that cross-country differences in banking regulations may encourage the flow of bank capital from markets that are heavily regulated to those markets that are less regulated. In one respect, this cross-country "regulatory competition" may enable banks to effectively evade costly regulations, which improves capital market efficiency and enhances global economic growth. Notwithstanding these potential benefits, there is a fear that this "regulatory competition" should more appropriately be viewed as a form of "regulatory arbitrage" that creates a "race to the bottom" which enables banks to circumvent prudent regulations and take excessive risks (Barth, Caprio and Levine, 2006, p.68). Given the interconnected nature of the financial markets and institutions, these types of regulatory arbitrage activities might expose all jurisdictions to the influence of excessive risk taking. ${ }^{2}$

Not surprisingly, these issues have received renewed attention in the aftermath of the recent financial crisis ${ }^{3}$. Moreover, the global crisis has spurred widespread calls for increased regulation and has also led both academics and practitioners to reaffirm the need for global coordination in bank

\footnotetext{
${ }^{1}$ The BIS monitors foreign claims held by banks from OECD countries vis-a '-vis the rest of the world .These claims represent banks' financial claims extended on residents outside the country in which these banks are headquartered. The claims consist of financial assets such as loans, debt securities, properties, and equities, including equity participations in subsidiaries (BIS, 2003).

${ }^{2}$ Reflecting these concerns about regulatory arbitrage, Acharya, Wachtel and Walter (2009, p.370) argue: "This will end up conferring substantial guarantees to the financial sector, giving rise to excessive leverage- and risk-taking incentives in spite of substantial regulation in each country.” Echoing these concerns, Naoyuki Shinohara, IMF's Deputy Managing Director, stated that:, "It is important to ensure a level playing field in regulation. Global coordination is needed to reap the benefits of global finance while minimizing the scope for regulatory arbitrage, which could be damaging to global financial stability".

${ }^{3}$ Indeed, as Knight (2009) points out, financial firms tend to take advantage of the regulatory gaps by engaging in regulatory arbitrage during the pre-crisis credit cycle upswing from 2002 to 2007, which made the financial system much less robust to shocks.
} 
regulation. ${ }^{4}$ For instance, the Basel Cross Border Resolution Group issued a report and recommendations on international coordination of bank regulation in March 2010 (BIS, 2010). IMF also issued a proposal "Resolution of Cross Border Banks-a Proposed Framework for Enhanced Coordination” in June 2010 (IMF, 2010). Despite the importance of these issues, to the best of our knowledge, no existing study has comprehensively examined the regulatory arbitrage incentives related to international bank flows. ${ }^{5}$ This historical omission is not altogether surprising because of the lack of available detailed data regarding cross-country bank regulations. However, recent global bank regulation surveys conducted by Barth, Caprio, and Levine (2004, 2006, 2008) help overcome this data availability issue. Utilizing this survey data to measure cross-country differences in banking regulations, our paper sets out to explore the extent to which regulatory arbitrage has taken place, and if so, its impact on global lending.

To address this issue, we take an in-depth look at global bank flows from 26 source countries to 120 recipient countries over the past decade. In testing for regulatory arbitrage, we explore whether differences in bank regulations have influenced the flow of bank capital across markets. Controlling for a large number of economic, legal and institutional factors that are likely to influence cross-country bank loans, we consider the effects of a wide range of banking regulations.

Our results strongly indicate that bank flows are positively related to the both the number of activity restrictions and the stringency of capital regulation imposed on banks in their source country, and negatively related to restrictions and regulations in the recipient country. Drilling further down, we consider the effects of specific regulations including restrictions on whether banks may own nonfinancial firms, the extent to which the bank supervisory authority is independent from the government, the degree of audit and disclosure transparency and the degree of power exerted by the supervisory authority. In each case, we find evidence that capital tends to flow from more restrictive to less restrictive jurisdictions.

These results appear to be robust to various time periods and various specifications. While we

\footnotetext{
${ }^{4}$ Morrison and White (2009) also address these issues in a theoretical context where they consider the costs and benefits of coordinated multinational regulation.

5 A much broader literature has examined the economic effects of cross-country differences in regulation and liberalization. See for example, La Porta, Lopez de Silanes, Shleifer and Vishny (1998), Bekaert, Harvey and Lundblad (2005), Barth, Caprio and Levine (2006), Laeven and Levine (2009) and Fernandes, Lei and Miller (2010)
} 
consistently find a strong association between the regulatory environment and bank flows, there is always the possibility of reverse causality where regulations endogenously respond to changes in capital market flows. While these econometric problems are common throughout the literature and difficult to complete eliminate (see Bekaert, Harvey and Lundblad (2005) for an excellent discussion of these issues) we take a variety of steps to alleviate these concerns. In particular, we follow the literature (e.g. Bekaert, Harvey and Lundblad, 2005; Bekaert, Harvey and Lundblad and Siegel, 2007) and control for exogenous measures of growth opportunities in our regression models, we use the fixed effect estimations to account for unobserved time-invariant country characteristics that may influence international bank flows, we estimate a series of models using instrumental variables, and we examine the effect of changes in bank regulations on changes of international bank flows. In each case, the main findings are upheld.

Furthermore, looking beyond just capital market flows, we also explore whether differences in regulations influence banks' decisions to establish foreign operation. Using bank level data across the 26 source countries ${ }^{6}$, we find strong evidence that regulatory gaps in activity restriction, capital regulation, supervisory independence and strength, external audit, disclosure transparency and loan classification exert significant impacts on banks' foreign expansion decisions. Overall, the bank level evidence strongly bolsters the findings that banks headquartered in more restrictive jurisdictions are more likely to establish a branch or subsidiary in the countries with lighter regulations.

Put together, all of these findings suggest that a form of regulatory arbitrage is taking place, and that banks tend to move funds to markets with fewer regulations ${ }^{7}$. More generally, our findings indicate that global banking regulations and the coordination of regulations across different markets have an important influence on the level of bank funding. On one level, it is not surprising that banks would want to take steps to avoid regulations. However, there are countervailing reasons why bank capital would not necessarily flock to low regulated markets, particularly if these countries do not have strong institutional and legal environments. Indeed, there are reasons to believe that in

\footnotetext{
${ }^{6}$ Using the Bankscope database, we compiled an original database on the operations of 301 large banks with headquarters in one of the 26 source countries covered in the BIS statistics, focusing on their foreign presence (i.e. branch or subsidiary) in 120 countries (i.e. the recipient countries in the BIS statistics) around the world. ${ }^{7}$ There exist some other types of regulatory arbitrage activities. For instance, banks exploited credit transfer mechanisms through setting up off-balance-sheet asset-back commercial paper conduits (ABCP) and structured investment vehicles (SIVs) and increased their effective leverage (Acharya et al., 2009).
} 
some circumstances strong regulations are prudent and may serve as a signal of quality and stability. ${ }^{8}$

To further disentangle these effects, we conduct a series of additional tests where we explore whether the level of economic development and the legal and institutional environment influence the degree of regulatory arbitrage. Here we find that cross-country differences in regulations have a much more profound effect on bank flows if the recipient country has an advanced economy, strong creditor rights, strong property rights and a high degree of information sharing among investors.

By confirming the importance of establishing a strong legal and institutional environment, these findings mitigate concerns of a possible "race to the bottom", to the extent they suggest that low regulations in isolation are not enough to attract capital. More negatively, our results suggest that even after controlling for these effects, banks do engage in a form of regulatory arbitrage. These actions may undercut attempts to limit risk-taking in the aftermath of the current crisis, unless policymakers are able to take the difficult steps to enhance the global coordination of banking regulations (Acharya, Wachtel and Walter, 2009).

Overall, we believe our results make an important contribution to two related literatures. First, our results contribute to the literature on international banking regulations (e.g. Barth, Caprio, and Levine, 2004, 2006; 2008; Beck, Demirguc-Kunt and Levine, 2006; Beck, Levine and Levkov, 2010; Houston, Lin, Lin, Ma, 2010; Laeven and Levine, 2009; Morrison, and White, 2009) by demonstrating the importance that these regulations have on the flow of bank capital across borders. To the extent our results highlight the need for regulatory coordination, we believe they also offer some insights to policymakers and regulators looking to rebuild the global regulatory architecture following the recent crisis. Second, our results add to the literature that has focused on the determinants of global bank activities (e.g. Focarelli and Pozzlo, 2001; La Porta, Lopex-de-Silanes and Shleifer, 2002; Buch, 2003; Mian, 2006; Sengupta, 2007; Dell’Ariccia and Marquez, 2010; Lin, Ma, Malatesta, Xuan, 2011 a\&b, Pang, Spint and Tice, 2010), by demonstrating the important effects that global banking regulations have on capital market flows. In this regard, we also contribute to the broader literature on the determinants of global capital flows (e.g. Gelos and Wei, 2005; Alfaro,

\footnotetext{
${ }^{8}$ For example, in a different setting, Fernandes, Lei and Miller (2010) explored the impact of a recent change in SEC guidelines which made it easier for foreign firms to avoid US guidelines regarding investor protections and disclosure. They showed that foreign firms operating in countries with weak investor protections saw a significant decline in their stock prices following the regulatory change, whereas there was no significant change in countries with strong investor protections.
} 
Kalemli-Ozcan and Volosovych, 2008; Papaioannou, 2009).The rest of the paper proceeds as follows: Section 2 describes the data used and presents a wide range of summary statistics. Section 3 explore the causes of global bank flows, and demonstrate the various channels in which regulatory systems in different markets affect the flow of foreign bank capital. Section 4 considers the impacts of regulatory difference across countries on bank foreign expansion decisions. Section 5 concludes.

\section{Data and summary statistics}

\subsection{Data sources}

Our study compiles data from four main sources:

(1) The International Banking Statistics published by the Bank for International Settlements (BIS) provides data regarding the international flow of bank loans and portfolio investments from 26 primarily OECD source countries to 120 recipient countries on a quarterly basis since December 1983. The BIS Consolidated/Nationality Banking Statistics publish foreign financial claims reported by domestic bank head offices, including the exposures of their foreign affiliates (i.e. branches and subsidiaries), and are collected on a worldwide consolidated basis after netting out inter-office positions (BIS, 2003, p.55). These claims comprise financial assets such as loans, debt securities, properties, and equities -- including equity participations in subsidiaries (BIS, 2003). The data are published in Table 9B of the BIS Quarterly Review regularly under the title, "The consolidated foreign claims of reporting banks”9.

This database provides comprehensive data on banks' financial claims extended on residents outside the country in which these banks are headquartered. It is important to stress that the bank's home country is determined by the reporting bank's nationality not its geographic location. So, for example, a loan issued by the US bank located in London to a British bank operating in London is recorded in the database as a foreign loan, where the source country is the US and the recipient country is the UK. However, a loan issued by the same US bank located in London to another US bank located in New York is regarded as a domestic loan issued by the US bank and is therefore not recorded in this database (for details, see Wooldridge, 2002).

(2) The Djankov, McLiesh, and Schleifer (DMS henceforth - 2007) and World Bank "Doing Business"

\footnotetext{
${ }^{9}$ A more detailed discussion about the data can be found in the Data Appendix.
} 
datasets provide information regarding creditor rights and information sharing measures in 129 countries during the past 30 years. More specifically, DMS (2007) dataset contains historical data on creditor rights and information sharing across 120 countries over the period 1978-2003 and "Doing Business” dataset contains more recent data updated annually.

(3) The Barth, Caprio, and Levine (BCL henceforth) (2004, 2006, 2008) dataset on bank regulation, supervision and monitoring in more than 100 countries. The database is compiled from three worldwide surveys of bank regulation and supervision among financial regulators. The original survey, Survey I, was conducted in 117 countries in year 1998. The first update in 2003, Survey II, characterized the regulatory situation at the end of 2002, and covered 152 countries. Survey III was conducted in 2005 and 2006 and covered 142 countries. The surveys contain more than 300 questions on various aspects such as capital regulation, entry regulation, activities restrictions, supervisory power and independence, external governance and monitoring. Overall, the three surveys plot a very detailed and comprehensive picture of global bank supervision and regulation over the past decade.

(4) The BankScope database provided by Bureau van Dijk and Fitch Ratings. The BankScope database has comprehensive coverage in most countries and accounts for over $90 \%$ of all banking assets in each country. Each bank report contains detailed balance sheet and income statement totalling up to 200 data items and 36 pre-calculated financial ratios. Using the Bankscope database, we compiled an original database on the operations of 301 large banks with headquarters in one of the 26 source countries covered in the BIS statistics, focusing on their foreign presence (i.e. branch or subsidiary) in 120 countries (i.e. the recipient countries in the BIS statistics) around the world. Due to the data availability on subsidiary and branch information, we focus on the most recent year in our analysis. The bank level accounting information is also obtained from the database.

In addition to the four main datasets mentioned above, we utilize a variety of other data sources. Specifically, we use the World Development Indicator (WDI, 2008) for macroeconomic control variables such as GDP per capita, population, and area. The common language dummy variable that equals one if the two countries share a common language or have former colonial relation is from Rose (2004). The financial market development index is from the Database on Financial Development and Structure constructed by Beck, Demirgüç-Kunt and Levine (2000) and it is updated regularly by its authors. We also used the index of financial liberation that was constructed by Abiad, 
Detragiache and Tressel (2010), and we followed the approach by Bekaert, Harvey, Lundblad and Siegel (2007) to construct the country level exogenous growth opportunity measure.

Tables 1 and 2 summarize these data sources and provide brief descriptions and summary statistics of the key variables. Below, we provide a quick overview of each of these key variables. A more detailed description can be found in the Internet Appendix.

[Tables 1 and 2 here]

\subsection{International Bank Flows}

The international bank flow measure is the main dependent variable in our analysis. This variable captures the bank capital inflows from banks located in source country $s$ to all sectors of the economy in recipient country $r$ from year $t-1$ to $t$. As there is no flow measure in the BIS data, we construct a bank flow measure by calculating the annual percentage change in total foreign claims for each source-recipient combination. More specifically, our main dependent variable is defined as 100 times the log-difference of total foreign claims (FCsr) from source country $s$ to recipient country $r$, that is, $100 * \Delta \ln$ FCsr. After merging different databases and deleting the missing observations, our sample covers international bank flow from 26 "source" countries ${ }^{10}$ to 120 "recipient" countries from 1996 to 2007. We construct the annual bank flow variable by using the stock data on December of each year in the sample period to match the annual frequency of the other explanatory variables ${ }^{11}$. As can be seen from Table 2, the sample mean of bank flow is 2.89, which suggests that the average bank flows from the source country to the recipient country in our sample increase by $2.9 \%$ a year over the sample period. The standard deviation of the bank flows is 11.32 , suggesting a great variation in international bank flow over time and across countries.

\subsection{Bank regulation and Supervision}

We use a set of variables from the three worldwide surveys conducted by Barth, Caprio and Levine over the past decade (Barth, Caprio and Levine, 2006, 2008) to measure various aspects of

${ }^{10}$ The 26 source countries/regions with available BIS bank flow data are: Australia, Austria, Belgium, Brazil, Canada, Chile, Denmark, Finland, France, Germany, Greece, Ireland, Italy, Japan, Mexico, Netherlands, Norway, Panama, Portugal, Spain, Sweden, Switzerland, Taiwan, Turkey, United Kingdom, and United States.

${ }^{11}$ We reduce the impact of outliers by trimming the bank flows outside the range between $-100 \%$ and $+100 \%$. That reduced our sample size by about $6 \%$. 
bank regulation and supervision across countries. These variables include two measures regarding restrictions on activities (Activities Restrictiveness and Bank Own Non-financial Firms), and a measure related to capital stringency (Capital Regulatory Index). We also use two variables to measure the strength of external auditors and financial statement transparency (Strength of External Audit and Financial Statement Transparency) two variables that are designed to measure the strength and independence of bank supervisors (Official Supervisory Power and Supervisory Independence) as well as a measure of the stringency in classifying loans that are in arrears (Loan Classification Lenience). Since the data span over the past decade, we focus on the time period 1996-2007. Specifically, the values of regulatory variables for the period of 1996 to 1999 are taken from the first survey recorded in 1998/1999. The values of regulatory variables for the period of 2000 to 2003 are taken from the second survey that assesses the state of regulation as of the end of 2002. The regulatory measures for the period of 2004 to 2007 are taken from the third survey that was recorded in 2005/2006. The detailed constructions and definitions of these variables can be found in Table 1 .

\subsection{Institutional Controls}

Previous studies (e.g. Alfaro et al., 2008; Papaioannou, 2009) highlight the important of institutional quality in driving the internal bank flows. We therefore control for the institutional difference between source and recipient countries using three sets of institutional variables regarding the level of creditor rights, information sharing and property rights.

We use the creditor rights index first established by La Porta, López-de-Silanes, Shleifer, and Vishny (LLSV henceforth - 1998), as a measure of the powers of secured creditors in bankruptcy. The index has been widely used in recent studies in finance literature (e.g. Houston et al., 2010; Acharya, Amihud and Litov, 2011). The level of information sharing among creditors is also likely to have an important influence on banks' willingness to provide foreign capital. Based on the data available from DMS (2007) and the World Bank "Doing Business" dataset, we construct a variable (Information Sharing), which indicates the contents of the credit information sharing through a public registry or private bureau. As a measure of property rights, we use the Legal Structure and Security of Property Rights index from the World Economics Freedom report constructed by the Economic Freedom Network. These institutional distance measures are panel data across 120 countries since the 1990s. 
Once again, detailed constructions and definitions of these variables can be found in Table 1

\subsection{Other Country Controls}

We also include several country-level variables to control for differences in economic development, institutions, and cultures across source-recipient country pairs. First, we control for the contract enforcement in both the source country and recipient country. The contract enforcement measures the average duration counted from the moment the plaintiff files the lawsuit in court until the creditors obtain payments. The proxy variable was first developed by Djankov, La Porta, Lopex-de-Silanes and Shleifer (2003), and have been updated in the World Bank's "Doing Business' database. In addition, we include real GDP per capita in US dollar to capture the economic development of the region/country. Third, we include the natural logarithm of population and area to capture the size of the market. Fourth, we include the common language dummy variable, which equals one if the two countries share a common language (Rose, 2004), to control for cultural and language differences between source and recipient countries. Furthermore, we include two variables to measure the banking sector structure in recipient countries. Banking Concentration is the share of the five largest banks in total bank deposits. Government Bank Ownership is the fraction of the banking system's assets in banks that are $50 \%$ or more owned by state government. State controlled banking sector with high concentration might deter the foreign banks from entering the market. Lastly, we also control for the geographical distance between the source and recipient countries to capture potential impacts of geographical distance on bank flow. To alleviate the concern that the empirical results are driven by some broader policy changes or the changes of growth opportunities, we also control for country wide financial liberalization (Abiad, Detragiache, and Tressel, 2010) and exogenous growth opportunities (Bekaert, Harvey and Lundblad, 2005, 2007) in a smaller subsample.

There is a concern that international bank flows might respond to "permanent income" shocks (e.g. productivity shocks) at the country level, and the institutions and regulations are partly shaped by these shocks as well. If this is the case, the observed relation between regulation and international bank flows might be spurious. To address this concern, we examined a correlation matrix of the key independent variables. We found that the change of income is not significantly associated with the 
changes of bank regulations and institutions, alleviating the concern of spurious correlation coefficients. To further address this concern, we control for income effects in all the regression analyses. $^{12}$

\section{Empirical Results: Regulatory Arbitrage and International Bank Flows}

\subsection{Regulation, Institution and Bank Inflows/Outflows}

In this section, we empirically test for regulatory arbitrage, relying on the three worldwide surveys conducted over the past decade by Barth, Caprio, and Levine (2006, 2008). Specifically, the values of regulatory variables for the period of 1996 to 1999 are taken from the first survey recorded in 1998/1999, the values of regulatory variables for the period of 2000 to 2003 are taken from the second survey that assesses the state of regulation as of the end of 2002, and the regulatory measures for the period of 2004 to 2007 are taken from the third survey that was recorded in 2005/2006 ${ }^{13}$. To help understand the various factors that influence cross-country bank flows, we construct a series of incremental tests. In these tests, we first isolate the factors influencing capital inflows into the recipient countries, and then separately examine the factors that influence the level of outflows from the source countries. In the subsequent sub-section, we will construct a gravity model that combines these effects by exploring the specific connections between source and recipient countries.

To examine the relation between bank regulation in recipient countries and bank capital inflows, we construct for each year, an aggregate bank inflow measure for each recipient country. We use this aggregate bank inflow measure as the dependent variable and estimate the following regression:

$$
\begin{aligned}
\text { Bank Inflow }_{r, t} & =\alpha_{0}+\alpha_{1} \text { Regulation }_{r, t}+\beta_{1} \text { Institutional Quality }_{r, t}+\gamma_{1} X_{r, t}+\varphi_{r}+\mu_{t} \\
& +\varepsilon_{r, t}
\end{aligned}
$$

where $r$ and $t$ respectively indicate the recipient country and time (year). The dependent variable Bank Flow is defined as 100 times the log-difference (from t-1 to t) of the aggregate total foreign claims (FCsr) from the 26 source countries to recipient country $r$. The independent variables include

\footnotetext{
12 This complete correlation matrix is included in the accompanying Internet Appendix (Appendix Table 1).

${ }^{13}$ We tried some alternative ways in assigning the values such as moving all the thresholds one year before or later and found the results quite robust. In addition, we also tried longer time period and found consistent results.
} 
a number of bank regulation and institution variables from the recipient countries. The regulatory variables include measures of activity restrictiveness, capital regulation, external audit, information disclosure, and supervisory power and independence, the details of which were discussed in Section 2. The institutional quality measures include the creditor rights index, the property rights index and the information sharing variable. The vector $X$ include standard controls such as GDP per capita, population and the country's land area. In addition, we also include recipient country $\left(\varphi_{r}\right)$ fixed effects and time fixed effect $\left(\mu_{t}\right)$. In addition, the heteroskedasticity-robust standard errors clustered at the recipient country level are used in computing $\mathrm{p}$-values. The estimated results from this model are reported in columns (1) to (6) in Table 3A.

[Table 3A here]

The results suggest that less stringent bank regulations in the recipient country induce more bank inflows. Looking more closely, we find that a higher level of activities restrictiveness in the recipient country discourages bank inflows. Holding other things constant, a recipient country with the lowest level of activity restriction in our sample is likely to attract 2.61\% higher bank inflow (on an annual basis) relative to the recipient country with the highest level of activity restrictiveness. A one unit increase in Restriction on Bank Owning Nonfinancial Firms in the source country results in a decrease the bank inflow growth by $0.86 \%$. Considering the sample mean $(2.89 \%)$ of the annual bank flow growth rate, the effects are economically important.

Moreover, we find that more stringent capital regulations are negatively associated with bank inflow growth in recipient countries. We also find that Strength of External Audit and Financial Statement Transparency are negatively associated with bank inflows into the recipient countries. A one standard deviation increase in Financial Statement Transparency index is associated with a decrease in bank inflow growth rate by $1.23 \%$. Considering the sample mean (2.89\%) of the annual bank flow growth rate, the effect is not trivial. Overall, the evidence suggests that higher information disclosure standards and stronger external governance tend to deter bank capital inflows. In addition, we find that the Independence of Supervisory Authority and Official Supervisory Power measures are negatively associated with bank inflows. The presence of an independent supervisor, for instance, is associated with a $1.25 \%$ decrease in bank inflow growth. The evidence suggests that bank capitals tend to flow into countries with less independent and weaker supervisory authority. We also find that 
loan classification leniency encourages bank inflows.

The measures of institutional quality also exert important influences on bank capital inflows. We find that information sharing, creditor rights and property rights protection in recipient countries are positively and significantly associated with bank capital inflows. For instance, a one standard deviation increase in Creditor Rights is associated with a 6\% increase in the annual growth rate of bank inflows. Furthermore, we find better contract enforcement in the recipient country also helps attract more bank inflows. Overall, the evidence indicates the importance of legal environment and investor protection in determining international bank flows.

Arguably, the international bank flows could also be driven by other important macro factors such as financial liberalization and growth opportunities. In order to alleviate the omitted variable concern, we include two additional controls in our baseline regression models. The first index is from a financial liberalization dataset compiled by Abiad, Destragiache and Tressel (2010). The index contains various dimensions including credit controls and reserve requirements, interest rate liberalization, entry barriers, capital account restrictions, privatization, and securities market policies and supervision. The dataset covers 91 countries across the sample period 1973-2005. A higher value indicates a higher degree of financial liberalization. The second index is a growth opportunity index, that is constructed using the approaches outlined by Bekaert, Harvey and Lundblad (2005) and Bekaert, Harvey, Lundblad and Siegel (2007). Intuitively, each country is viewed as a composition of sectors each with time-varying growth opportunities, which are reflected in the $\mathrm{P} / \mathrm{E}$ ratios (price to earnings ratios) of global industry portfolios (Bekaert, Harvey and Lundblad, 2005). Following Bekaert, Harvey and Lundblad (2005), an annual measure is constructed based on the 3-digit SIC industry composition for each country and weighted by their output shares according to UNIDO Industrial Statistics Database. As Bekaert, Harvey and Lundblad and Siegel (2007) point out, this measure of exogenous growth helps address many of the endogeneity concerns in the cross country finance and growth literature.

After including these two new controls, the sample size drops to 642 (columns 7). However, all the main findings remain significant and robust. Moreover, we find that both Financial Liberalization and Growth Opportunities are associated with a higher bank inflow growth rate. In column (8), we re-estimate the regressions using weighted OLS regressions (the results are weighted by the size of the 
recipient countries measured by GDP in USD). As can be seen from the table, the empirical results remain highly robust.

Next we turn our attention to the factors that influence bank outflows. Here, we aggregate the bank outflow data from each source country to 120 recipient countries in a specific year and construct a source country/year aggregate bank outflow measure. We use this aggregate bank outflow measure as the dependent variable and estimate the following regression:

$$
\begin{gathered}
\text { Bank Outflow }_{s, t}=\alpha_{0}+\alpha_{1} \text { Regulation }_{s, t}+\beta_{1} \text { Institutional Quality }_{s, t}+\gamma_{1} X_{s, t}+\varphi_{s}+\mu_{t} \\
+\varepsilon_{s, t}
\end{gathered}
$$

where $s$ and $t$ indicate the source country and time (year), respectively. The dependent variable Bank Flow is defined as 100 times the log-difference (i.e. difference in log from t-1 to t) of aggregate total foreign claims (FCsr) from a source country s to 120 recipient countries. The key independent variables are the same measure of bank regulation, institutional quality and other controls used above, but now we capture these measures from the source countries. We also include source country $\left(\varphi_{s}\right)$ fixed effects and time fixed effect $\left(\mu_{t}\right)$. In addition, the heteroskedasticity-robust standard errors clustered at the source country level are used in computing p-values. The estimated results from this model are reported in columns (1) to (6) in Table 3B. In column (7), we further include Financial Liberalization and Growth Opportunities as additional control variables to address the potential omitted variable concern. The sample size drops from 238 to 181. In column (8), we re-estimate the regressions using source country size weighted OLS regressions and test the robustness of the results.

\section{[Table 3B here]}

As can be seen from the table, the results are highly consistent with our previous findings. Specifically, we find that Overall Activities Restrictions and Restriction on Bank Owning Nonfinancial Firms are associated with a higher growth rate of bank capital outflows. In other words, higher level of activities restrictiveness in the source country encourages bank outflows. We also find that capital stringency, financial statement transparency and the strength of external audit are all positively associated with bank outflow growth. Likewise, we find that bank capital tends to flow from countries with more independent and powerful supervisory authority to countries with less independent and weaker supervisory authority. Moreover, loan classification leniency tends to discourage bank outflows.

The institutional quality also significantly affects bank capital outflows. The measures related to 
information sharing, creditor rights and property rights protection in source countries are negatively and significantly associated with bank capital outflows. Moreover, we find better contract enforcement in the recipient country also helps reduce bank outflows. Overall, the evidence suggests that higher institutional quality discourages bank outflows.

Next to get a more visual sense about the relation between regulation and bank inflows out outflows, we constructed a series of non-parametric (kernel-weighted local polynomial smoothing) plots of the relation between regulatory changes and the changes of bank inflow (outflow) growth in recipient (source) countries. As Barth et al. (2008) point out, a large number of bank regulatory changes have occurred in various countries over the past decade. In Appendix Figure 1, we follow Barth et al. (2008) to make comparisons on bank activities restrictiveness in year 1999 (using Survey I) and year 2006 (using Survey III). A change in a positive direction indicates a move towards greater restrictiveness. As can be seen, most countries tightened restrictions during the past decades. The activities restrictiveness in many developing countries such as Vietnam, Nicaragua, Dominica Republic, and Costa Rica increased dramatically over the past decade. At the same time, restrictions have eased in some countries such as Mexico, Belgium, Oman, and Romania ${ }^{14}$. Overall, among the 120 recipient countries in our sample, we find that 114 recipient countries/regions have changed at least one type of regulations during the past decade. Among the 26 source countries in our sample, we find that 21 countries/regions have changed at least one type of regulations during the past decade. In Figure 1, we present the non-parametric plots with the changes in regulations of recipient countries on the $\mathrm{X}$-axis, and changes in bank inflow growth on the Y-axis. In Figure 2, we present the non-parametric plots with the changes in regulations of source countries on the $\mathrm{X}$-axis, and changes in bank outflow growth on the Y-axis. We focus on the three survey years (1999, 2002, and 2005) to measure the regulatory changes. To capture the potential lagged effects of regulatory changes, we use bank flow data in years 2001, 2004, and 2007 data to measure the changes in bank flows.

[Figures 1 and 2 here]

These plots largely confirm our findings in the regression analyses. In Figure 1, we find a negative relation between the changes in various dimensions of bank regulation (i.e. overall activities

\footnotetext{
${ }^{14}$ There are also significant changes on other dimensions of regulation such as capital regulatory stringency, financial statement transparency, official supervisory power and loan classification leniency. Please see Barth et al. (2008) for detailed discussions and comparisons.
} 
restrictiveness, restriction on banks own non-financial firms, capital regulatory stringency, strength of external audit, financial statement transparency, independence of supervisory authority and official supervisory power) and the changes of bank inflows. In Figure 2, we find a positive relation be between the changes in various dimensions of bank regulation (i.e. overall activities restrictiveness, restriction on banks own non-financial firms, capital regulatory stringency, strength of external audit, financial statement transparency, independence of supervisory authority and official supervisory power) and the changes of bank outflows. Moreover, we find a negative relation between the changes in loan classification leniency and the changes of bank outflows. Taken together, these plots lend credence to our regression findings, provide assurance that the results are not driven by a few outliers and at the same time, perhaps provide a clearer picture of the links between regulations and capital market flows.

\subsection{Regulatory Arbitrage and International Bank Flows: Gravity Model}

In this section, we combine the "push" and "pull” effects on international bank flows and estimate the following standard "gravity" model with country and time fixed effects.

$$
\begin{aligned}
& \text { Bank Flow }_{s, r, t}=\alpha_{0}+\alpha_{1} \text { Regulation }_{s, t}+\alpha_{2} \text { Regulation }_{r, t}+ \\
& \beta_{1} \text { Institutional Quality }_{s, t}+\beta_{2} \text { Institutional Quality }_{r, t}+\gamma_{1} X_{s, t}+\gamma_{2} X_{r, t}+ \\
& \theta_{1} \ln \left(\text { Distance }_{s, r}\right)+\theta_{2}{\text { Common } \text { Language }_{s, r}+\eta_{s}+\varphi_{r}+\mu_{t}+\varepsilon_{s, r, t}}^{\text {(3) }}
\end{aligned}
$$

where $s$ and $r$ indicate the source and recipient country, respectively, and $t$ indicates time (year). The dependent variable Bank Flow is defined as 100 times the log-difference of the ratio of total foreign claims (FCsr) from source country $s$ to recipient country $r$, that is, $100 * \Delta \ln (F C s r)$. The key independent variables are the same measures of the regulatory environment, institutional quality and other controls used earlier but now we include these variables from both the source and recipient countries. In addition, two other measures are now included. Potential information frictions and transaction costs are captured by the logged distance between the source and recipient countries. Common language is included to control for potential cultural and language differences between the source and recipient countries. In addition, we also include source country $\left(\eta_{s}\right)$ and recipient country $\left(\varphi_{r}\right)$ fixed effects to capture the time-invariant country-specific characteristics in the source and recipient countries, respectively. The model also includes a time fixed effect $\left(\mu_{t}\right)$ In addition, the 
heteroskedasticity-robust standard errors clustered at the recipient country level are used in computing pt-values. The estimated results from this model are reported in columns (1) to (6) in Table 4. After excluding the missing observations, the sample size is about 14,000 observations. In column (7), we further include Financial Liberalization and Growth Opportunities as additional controls to address the potential omitted variable concern. The sample size drops to 7923. In column (8), we employ the panel generalized method of moments (GMM) estimator described in Bekaert, Harvey, and Lundblad (2001) to accommodate heteroskedasticity both across countries and across time and correlation between country residuals (Bekaert, Harvey and Lundblad, 2005) and test the robustness of the results. As can be seen from the table, the empirical results remain highly robust to the GMM estimation.

[Table 4 here]

Table 4 provides strong evidence the bank capital flows from heavily regulated markets to those markets that are more lightly regulated. Specifically, we find that a lower level of activities restrictiveness in the recipient country induces more bank inflows while higher level of overall activities restrictiveness in the source country encourages more bank capital outflows. Holding other things constant, a recipient country with the lowest level of activity restriction in our sample is likely to attract $2.25 \%$ higher bank inflow (on an annual basis) relative to the recipient country with the highest level of activity restrictiveness. A one unit increase in Bank Owning Nonfinancial Firms in the source country results in a 1.3\% increase in bank outflow growth; a one unit increase in Bank Owning Nonfinancial Firms in the recipient country decreases the bank inflow growth by $1.97 \%$. Considering the sample mean (2.89\%) of the annual bank flow growth rate, the effects are economically important.

Regarding capital regulation, we find that capital regulatory stringency is positively associated with bank outflow growth in source countries and negatively associated with bank inflow growth in recipient countries. A one standard deviation increase (1.78) in the Capital Regulatory Index increases the bank outflow growth by $1.05 \%$ in the source country and decrease the bank inflow growth by $0.77 \%$ in the recipient country. In short, the evidence indicates that bank capital tend to flow from markets with more stringent capital regulation to the markets with lower capital regulatory stringency.

We also find that bank capital flows from countries with higher information disclosure standards and stronger external audit to countries with weak disclosure and audit. Specifically, the Strength of External Audit and Financial Statement Transparency are positively associated with bank outflows in 
the source country and negatively associated with bank inflow in the recipient country. A one standard deviation increase in Financial Statement Transparency in the source country results in a $1.6 \%$ increase in bank outflow growth; a one standard deviation increase in Financial Statement Transparency in the recipient country decrease the bank inflow growth by $0.93 \%$. In some specifications, however, the coefficients are marginally significant or insignificant.

With respect to bank supervision, we find that bank capitals flow from countries with more independent and powerful supervisory authority to countries with less independent and weaker supervisory authority. A one standard deviation increase in Official Supervisory Power in the source country results in a $1.29 \%$ increase in bank outflow growth; a one standard deviation increase in Official Supervisory Power in the recipient country decrease the bank inflow growth by $1.15 \%$. We also find that supervisor independence in the recipient country tends to discourage international bank inflows while the effect of supervisor independence in the source country is only marginally significant. A one unit increase in Supervisory Independence in the recipient country decreases the bank inflow growth by $0.65 \%$. Moreover, we find that bank capital tends to flow from countries with stringent loan classification systems to countries with more lenient loan classification systems. Overall, the empirical results show that banks do take advantage of regulatory gaps across countries and that bank capital flows from markets that are heavily regulated to those markets with less activity restrictions, lower stringency in capital regulation, weak external audit and disclosure transparency, lower entry barriers, weak supervisory authority and lenient loan classification criteria.

Consistent with the literature, the institutional distance between source and recipient countries exerts a very significant impact on international bank flows. On the one hand, we find that better information sharing, stronger creditor rights protection and property rights protection in recipient countries are associated with more bank capital inflows. On the other hand, we find that among the source countries with better information sharing, stronger creditor rights protection and property rights protection, there tends to be fewer bank capital outflows. Furthermore, we find better contract enforcement in the recipient country also helps attract more bank inflows. However, concentrated and state controlled local banking sector tends to deter the bank capitals from flowing into the recipient countries. In column (7) and (8), we find that growth opportunities at source countries discourage bank outflows while growth opportunities at recipient countries attract bank inflows. 
We also perform three robustness tests. First, we consider various approaches for estimating the standard errors in our panel data. Here we use the estimation approaches suggested by Petersen (2009) to test the robustness of the results to the clustering by two dimensions. As Petersen (2009) points out, in many cases, clustering by two dimensions help reduce biases in standard errors in panel studies. Specifically, we test the robustness to clustering by recipient country and time, clustering by source country and time, and clustering by recipient-source country pair and time and find the results highly consistent to our main findings.

Second, we calculate for the key regulatory and institutional variables, the regulatory gaps between each source and recipient country, and use these as alternative explanatory variables. The results are very similar to those based on the gravity functions. Third, we examine the effects of regulatory changes on international bank flow changes. Focusing on changes allows us to account for unobservable time-invariant country specific characteristics that might influence both the level of bank regulation and international bank flows. This approach also helps alleviate the endogeneity concern (Lin et al., 2011). The details and the reported results for each of these tests can be found in the accompanying Internet Appendix (Table 3 and 4).

\section{3. Instrumental Variable Analysis}

The above results demonstrate that cross-country bank flows are strongly associated with the regulatory and institutional environment of the source and recipient countries. While we argue that these results are consistent with regulatory arbitrage, reverse causality remains a possibility - and rather than being exogenous, the regulatory and institutional environment in a given country may respond to changes in capital flows. Certainly, these are common concerns that are often cited in the finance and growth literature. As pointed out by Bekaert, Harvey and Lundblad (2005), it is very difficult to fully address this issue, but we have taken several steps to try to alleviate these concerns. First, we follow Bekaert, Harvey and Lundblad (2005) and use the measure of exogenous growth opportunities as an additional control to address the potential endogeneity issue. As Bekaert, Harvey, Lundblad and Siegel (2007) point out, "Such a measure should prove useful in numerous empirical studies seeking to avoid endogeneity problems”. In addition, we use the fixed effect estimations to account for unobserved time-invariant country characteristics that may influence international bank 
flows. To further ameliorate this concern, we provide a series of robustness tests using instrumental variable analysis and change regressions. In this sub-section, we will present and discuss the empirical results of instrumental variable analysis. We will discuss the change regression results in the subsequent sub-section.

We first select the instrumental variables based on the theoretical and empirical work in the law, institution and finance literature (Acemoglu and Johnson, 2005, Beck, Demirgüç-Kunt and Levine, 2003, Easterly and Levine, 1997). The literature highlights the important roles of geographical endowment and ethnic fractionalization in shaping the political and financial institutions (Acemoglu et al., 2001, Beck et al., 2003, Easterly and Levine, 1997). Beck et al. (2003, 2006) and Barth et al. (2009) find strong evidence that geographical endowment and ethnic fractionalization exert substantial impacts on the formation of financial regulation and institutions. We therefore follow Beck et al. (2006) and use latitude and ethnic fractionalization as instrumental variables for the financial regulation measures. Following Beck et al. (2006), we also include the percentage of years that the country has been independent since 1776 as an additional IV because countries that gained their independence earlier had more chance to adopt regulations more valuable to economic development.

Moreover, the literature has documented the possibility of "regulation contagion". As Demirgüç-Kunt and Detragiache (2002) point out, policymakers and regulators are influenced by the choices of policymakers in other countries. As the policy or regulation become more widespread, it becomes enshrined as fort of "universal best practice", and countries are more likely to adopt it. Furthermore, regulators or policymakers may learn more about the workings of the regulation from those countries implementing the regulation. Therefore, regulators might modify their regulation after observing regulatory changes in other countries. We follow Demirgüç-Kunt and Detragiache (2002) and use the sample mean of the financial regulation measures at a specific year as additional instruments to capture the dynamic trend of regulatory changes.

We also select the instrumental variables based on the supervisory structure and other macroeconomic characteristics. First, we create a dummy variable (central bank regulator) which equals one if the central bank is the bank regulator. As argued by Goodhart (2000), central banks care more about macro-economic monetary and price stability, which rests on the basis of maintaining the micro-level financial stability in the banking system. Therefore, central banks as the bank regulators 
are more likely to adopt prudential regulations that will keep the systemic stability. We also use the average experiences of a professional bank supervisor as an additional control. The data is obtained from Barth et al., (2008). More experience bank supervisors are more likely to adopt the state-of-art bank regulations that help address various issues in the banking system. Moreover, we use the Gini coefficients as a measure of income inequality (past 5-year moving average) as an additional instrumental variable. As pointed out by Beck, Levine and Levkov (2010), “an influential political economy literature stresses that income distributional considerations, rather than efficiency considerations, frequently exert the dominant influence on bank regulation”. As discussed above, these variables are likely to affect the bank regulations. At the same time, these variables per se are unlikely to exert a direct, first-order effect on the international bank flows. We therefore use them as additional instrumental variables in our analysis ${ }^{15}$. The empirical results are presented in Table 5.

[Table 5 here]

As can be seen from Table 5, the empirical results are rather robust. The coefficients of regulation and supervision variables in recipient countries remain positive and significant while the coefficients for these variables in source countries remain negative and significant. The results strongly confirm our finding that bank capital tends to flow from markets that are heavily regulated to those markets that are lightly regulated. Other controls also yield qualitatively similar results.

Furthermore, the IV coefficients are somewhat larger than the OLS coefficients, indicating the existence of potential measurement error in the original results, which would tend to "attenuate" the coefficient estimate toward zero (Rajan and Subramanian, 2008; Barth et al., 2009). Following the literature (e.g. Beck et al., 2006), we conduct two tests to assess the appropriateness of the instruments. First, we employ the overidentifying tests, which assess whether the instrumental variables are associated with the dependent variable beyond their effects through bank regulation and supervision or the other explanatory variables. We report the p-value of the test of the overidentifying restrictions. Failure to reject the null hypothesis implies a failure to reject the validity of the instruments. As can be seen from Table 6, we cannot reject the null hypothesis that the instruments are valid in all model

\footnotetext{
${ }^{15}$ We also considered some other potential instrumental variables including a measure of press freedom. In a country with greater press freedom, people are more likely to get access to all sorts of information and express their voice. As a consequence, a country with greater press freedom is more likely to adopt state-of-art and appropriate regulation schemes. The empirical results are highly robust to the inclusion of this potential instrumental variable.
} 
specifications, suggesting that these instruments only exert an impact on international bank flows through their effect on banking regulation and supervision. In addition, we conduct an F-test of the excluded exogenous variables in the first-stage regressions. We reject the null hypothesis that the instruments do not explain cross-sectional differences in bank regulation and supervision at the $1 \%$ level in all model specifications. The p-values of the F-tests are reported in the last row of Table 6. Similar to the claim made in Beck et al. (2006), we are not arguing that these variables are the best instrumental variables. Instead, we hold that the instruments are reasonably exogenous and have decent explanatory power in explaining the bank regulation and supervision measures.

\subsection{Regulatory Arbitrage: Does Institutional Quality Matter?}

Despite the above results, there are countervailing reasons why bank capital would not necessarily flow to low regulated markets, particularly if these countries do not have strong institutional and legal environments. Indeed, there are reasons to believe that in some circumstances strong regulations may actually signal quality and stability, and therefore help attract capital inflows. To further disentangle these effects and to better understand the economic context of regulatory arbitrage activities, we conduct a series of additional tests to explore whether the level of economic development and the legal and institutional environment influence the degree of regulatory arbitrage.

We split the sample based on time period, economic development and institutional quality (i.e., creditor rights, information sharing and property rights) and conduct regression analysis for each sub-sample.

A country with an equal or above median institutional quality score is viewed as a country with better institution. We then combine the above three individual institution quality indicators to obtain an aggregate measure of the overall institution quality for each country. For each individual indicator, we assign a value of one to a high quality country and zero to a low quality country. Then we sum the scores of each country across the three indicators to obtain the overall measure of institution quality of a country. The value of this aggregate measure goes from zero (lowest institution quality country) to three (highest institution quality country). If the aggregate measure of a country is equal or above the sample medium level, the country is defined as an overall high quality institution country. We then split the sample based on the overall institutional quality measure. The empirical results are presented 
in Table 6.

[Table 6 here]

The first cut in columns (1) and (2) corresponds to the different time periods. We find regulatory arbitrage patterns in both sub-periods (1996-2001 and 2002-2007) though the effects are somewhat stronger in the latter period. In columns (3) and (4), we find regulatory gaps exert significant effects on bank flows to both developed countries and developing countries, however the effects on bank flows to developed countries are much more profound. Perhaps, not surprisingly, these results suggest that the incentives to engage in regulatory arbitrage are much stronger within the set of developed countries. The next set of tests explore whether the main results vary depending on the differences in the three measures of institutional quality (level of creditor rights, degree of information sharing and property rights protection). In each case, countries with measures above the median level are characterized as having high institutional quality, while those below the median are characterized as having low quality. Looking at these results in columns (5) to (10), we find strong evidence that cross-country differences in regulations have a much more profound effect on bank flows if the recipient country has stronger creditor rights, stronger property rights and a high degree of credit information sharing. Finally, we construct an overall measure of institutional quality by simply summing the three individual measures (varying from 0 to 3 - where a measure of 3 indicates that the country is above the median in terms of creditor rights protection, information sharing and property rights protection). Using the overall institutional quality index (columns 11 and 12), we find that the regulatory arbitrage effects are much stronger for the recipient countries with better institutional quality.

While we have focused on how the regulatory, institutional and legal environment influence bank flows, it is also worth considering whether these variable influence other aggregate key measures related to global finance. For example, there is a large literature that looks at the determinants of the current account - and with this in mind, we consider separately how our key variables influence the current account.

Using the current account as a proxy for aggregate capital outflows, we find that overall activities restrictiveness, restriction on whether banks can own non-financial firms, capital regulation stringency, strength of external audit, financial statement transparency and independence of supervisory authority 
are positively associated with aggregate capital outflows. Furthermore, we find that better institutional quality (i.e. stronger creditor rights, property rights, better contract enforcement and information sharing) are associated with lower degree of capital outflows. Overall, the empirical results are highly consistent with our previous findings that used bank flows as the dependent variable. The details of our estimating framework and the corresponding results are presented in the Internet Appendix Table 5.

\section{Empirical Results: Regulatory Arbitrage and International Bank Expansions}

As discussed earlier, international banks may grow their foreign claims portfolio through two channels: (1) establishing affiliates in different countries and extend claims locally through their branches and subsidiaries in these countries, and (2) extending cross-border claims by financing and booking the claims from outside the recipient or host countries. Arguably, the regulatory arbitrage incentives have more of an effect on the first channel since the cross-border claims by the bank headquarter are often subject to the regulation in the source country. In this section, we try to provide more direct evidence about the regulatory arbitrage incentives and banks foreign expansion strategies that require a physical presence aboard (i.e. subsidiary or branch). We obtain bank level data including information on the bank foreign affiliates from Bankscope, which has comprehensive coverage in most countries, and accounts for over $90 \%$ of all banking assets in each country. Following the literature (e.g. Focarelli and Pozzolo, 2005), we compiled an original database on the operations of 301 large banks (total assets> \$25 billion USD) with headquarters in one of the 26 source countries covered in the BIS statistics, focusing on their foreign presence (i.e. branch or subsidiary) in 120 countries (i.e. the recipient countries in the BIS statistics) around the world. Information on branches and foreign subsidiaries refers to year $2008^{16}$. After dropping some missing observations, we obtain more than 35,000 paired bank-country observations. To get some sense about the relation between the presence of bank foreign affiliates and international bank flows, we check the country pairs where the bank inflows are most out of the ordinary ${ }^{17}$ and find that the percentage of country pairs that the

\footnotetext{
${ }^{16}$ The information is available in Bankscope only over the most recent years.

${ }^{17}$ Specifically, we omit the eight pairs of bank supervision and regulation variables for both the source and recipient countries in equation 7 of Table 4 and run an additional regression with other controls. We then calculate the mean of the residuals for each source-recipient country pairs based on the regression results. We sort the residuals and focus on the country pairs with the top $5 \%$ of the largest positive residuals.
} 
source country has banking affiliates in the recipient country is about $71 \%^{18}$. Moreover, there exist significant regulatory gaps in the majority of these country pairs.

The empirical analysis broadly examines whether banks with headquarters in heavily regulated countries are more likely to have a foreign subsidiary or branch in countries with fewer supervisory and regulatory restrictions. To explore this issue, we estimate the following probit model:

$\operatorname{Pr}\left(Y_{i, s, r}=1\right)=f\left(\right.$ Regulation $_{s}$, Regulation $_{r}$, Institutional Quality ${ }_{s}$, Institutional Quality ${ }_{r}$, Bank Chracteristics $_{i}$, Country Control $_{s}$, Country Control $r$, Distance $_{s, r}$, Common Language $_{s, r}$ )

where $f(\cdot)$ is the standard normal cumulative distribution (cdf) in the Probit model, which can be expressed as $f(z)=\Phi(z)=\int_{-\infty}^{z} \phi(v) d v$, where $\phi(\cdot)$ is the standard normal density.

$Y_{i, s, r}=1$ when the bank i of country s has foreign affiliates (subsidiaries or branches) in country r, and zero otherwise (Foreign Presence). Alternatively, we define $Y_{i, s, r}=1$ when the bank i of country s has foreign subsidiaries in country r, and zero otherwise (Foreign Subsidiary). The foreign subsidiaries are locally charted and independently capitalized so that it is clear that they only need to operate under the host country's regulation. Therefore, it might be a cleaner setting to test for regulatory arbitrage incentives by focusing on the bank foreign subsidiaries. Following Focarelli and Pozzolo (2005), subsidiaries refer to locally incorporated banks with the presence of foreign ownership $^{19}$. The empirical results are presented in Table 7. Columns (1) to (5) and (7) are estimated using Foreign Subsidiary as the dependent variables, while column (6) is based uses Foreign Presence as the dependent variable. In columns (7), we include growth opportunities and financial liberalization

\footnotetext{
${ }^{18}$ For example, among these pairs, Portuguese banks have affiliates in Poland and Franc, and Japanese banks have affiliates in Italy, France and Philippines. Among these pairs, we also find that banks in Spain and Switzerland have affiliates in Germany, . Denmark banks have affiliates in U.K. and Lithuania, and U.S. banks have affiliates in Norway, Romania, Sweden and U.K .have affiliates in U.K. and Lithuania. U.S. banks have affiliates in Norway, Romania, Sweden and U.K.

${ }^{19}$ In principle, one would like to find a minimum percent of equity interest needed to ensure the effective control powers in determining the bank's activities. 50\% share might be too stringent because the effective control definitely depends on the distribution of ownership (Focarelli and Pozzolo, 2005). We therefore follow Focarelli and Pozzolo (2005) and define foreign subsidiaries as all banks with a shareholder out of the country, without any participation threshold. We also test the robustness of the results using more stringent definition that a subsidiary refers to locally incorporated banks with the more than $50 \%$ foreign ownership. The empirical results are highly robust.
} 
as additional control variables.

[Table 7 here]

As can be seen from Table 7, the empirical results are highly consistent with our previous findings. Specifically, we find that banks in countries with more activities restrictions, stringent capital regulations, higher disclosure requirements, strong external audit, powerful and independent supervisor, and more stringent loan classification are more likely to expand abroad by establishing subsidiaries and/or branches. Regarding the host country's characteristics, we find that international banks are more likely to set up subsidiaries or branches in countries with fewer activities restrictions, less restrictive capital regulations, lower disclosure requirements, weak external audit and supervisor, and lenient loan classifications. The empirical results are both statistically significant and economically significant. For instance, a one standard deviation increase in Activities Restrictions in the source country increases the likelihood of bank's foreign expansion by about 6\% (column 1) to 10\% (column 7). In contrast, a one standard deviation increase in Activities Restrictions in the host country decreases the likelihood of foreign bank’s presence by about 4\% (column 1) to 8\% (column 7). A one unit increase in Bank Owning Nonfinancial Firms in the source country results in a 6\% increase in the likelihood of bank's foreign expansion; a one unit increase in Bank Owning Nonfinancial Firms in the recipient country decreases the likelihood of foreign bank's presence by $5 \%$. Considering the sample mean (6\%) of the foreign expansion tendency (Foreign Subsidiary Dummy), the effects are economically important.

The other aspects of regulation and supervision also yield significant results. For instance, a one standard deviation increase in Supervisory Power in the source country increases the likelihood of bank's foreign expansion by about $10 \%$ (column 6); while a one standard deviation increase in Supervisory Power in the host country decreases the likelihood of foreign bank's presence by about 12\% (column 6). Regarding the market monitoring, a one standard deviation increase in Strength of External Audit in the source country increases the likelihood of bank's foreign expansion by about 7\% (column 6); a one standard deviation increase in Strength of External Audit in the recipient country decrease the likelihood of foreign bank's presence by $6 \%$.

Moreover, we find that larger banks with higher net income are more likely to expand abroad. Overall, the empirical results show that cross country regulatory differences play an important role in 
the banks' foreign expansion decisions.

To understand the effects more intuitively, we also do a simple matching analysis. First, for each of the 26 source countries, we create dummy variable related to each of the eight supervision and regulation measures used in our previous analysis. For each dummy variable, we assigned a value of 1 to countries which have a more stringent regulation relative to the sample median. We then construct the overall regulation index as the sum of these eight dummy variables. Thus, this overall measure ranges from 0 to 8 with a higher value indicating a higher level of bank regulation. We divide 26 source countries into two groups of high/low regulation according to the overall regulation index of each country being above or below the medium level of the index.

Next, we divide all 301 banks from the 26 source countries into big/small or high profitability/low profitability banks according to their size and net income relative to the respective medians. This gives us a total of four cells. For the four cells, we conduct four t-tests to see within each cell if banks located in highly regulated countries have more oversea subsidiaries than banks located in less regulated countries. In three out of the four cells (except small and low profitability banks), we find significant evidence that banks located in highly regulated countries tend to have more oversea subsidiaries than banks located in less regulated countries ${ }^{20}$. The results bolster the findings from our probit regression analysis.

\section{Conclusion}

In the aftermath of the recent financial crisis, there has been an ongoing discussion regarding the need to change the regulatory architecture of the global financial system. Many have stressed the need for more vigilant regulation, but a common concern is that financial institutions may be able to avoid regulations by shifting their business to less regulated markets. This potential for regulatory arbitrage may therefore increase the benefits of coordinating regulations across financial markets. At the same time, there are benefits to allowing different regulations in different markets, which may limit the need for coordination if the risk of regulatory arbitrage is minimal.

With these issues in mind, this paper has explored in detail how differences in bank regulations have affected the flow of capital across markets over the past decade. Our results

${ }^{20}$ The results are presented in Table 6 in the Internet Appendix. 
suggest that there are important "push and pull” effects where controlling for other factors, capital is more likely to flow from those markets with restrictive regulations to those markets that have fewer and more relaxed restrictions on bank capital and bank investment opportunities. These results confirm that a form of regulatory arbitrage is taking place where banks tend to transfer funds to limit their regulatory tax. In one respect, these results suggest that one way a developing country can attract foreign capital is by establishing fewer regulations. In a positive sense, this form of cross-country competition may help put the brakes on any over- regulation of the global financial sector. More negatively, these results lend support to the concerns raised by Acharya et. al. (2009) regarding a global "race to the bottom" where capital flows to the least regulated environment. The concern is that in an interconnected global environment we all bear the risk associated with banking crises that arise due to insufficient regulation in any given market. These concerns are particularly relevant in the context of the current financial crisis, and at the very least, our results reinforce the need for global coordination in banking regulations.

At the same time, we hasten to add that our results do not necessarily suggest that there should be always be complete coordination in banking regulations. Once can certainly argue that cross-country differences in regulations can often promote innovation. Moreover, other differences in the economic, legal and institutional environment may make it such that one size doesn't fit all when it comes to banking regulation. More practically, real-world political considerations often limit regulators' ability to coordinate effective regulations. ${ }^{21}$ One possible solution is to start international coordination among large developed economies since the regulatory arbitrage activities tend to be more prevalent in these economies. In summary, while we think our results are instructive and highlight the concerns regarding regulatory arbitrage, when it comes to the details regarding the global coordination of banking regulations there is obviously a lot of room for future research.

\footnotetext{
${ }^{21}$ See Lannoo (2009) for a good discussion of the challenges involved in coordinating regulations within the European Union in the aftermath of the recent financial crisis.
} 


\section{References}

Abiad, Abdul, Enrica Detragiache, and Thierry Tressel, 2010. A New Database of Financial Reforms, IMF Staff Papers 57, 281-302.

Acemoglu, Daron, Simon Johnson and James A. Robinson, 2001, The colonial origins of comparative development: An empirical investigation, American Economic Review 91, 1369-1401.

Acemoglu, Daron and Simon Johnson, 2005, Unbundling institutions, Journal of Political Economy 113, 5, 949-995.

Acharya, Viral V., Paul Wachtel, and Ingro Walter, 2009. International Alignment of Financial Sector Regulation, in "Restoring Financial Stability: How to Repair a Failed System", edited by Viral V. Acharya and Matthew Richardson, New York University Stern School of Business, John Wiley \& Sons, March 2009.

Acharya, Viral V., Yakov Amihud, and Lubomir Litov, 2011. Creditor Rights and Corporate Risk-Taking, Journal of Financial Economics 102, 150-166.

Alfaro, Laura, Sebnem Kalemli-Ozcan, and Vadym Volosovych, 2008, Why Doesn't Capital Flow from Rich to Poor Countries? An Empirical Investigation, Review of Economics and Statistics 90, 347-368.

Barth, James, Gerad Caprio, and Ross Levine, 2004, Bank regulation and supervision: What works best? Journal of Financial Intermediation 13, 205-248.

Barth, James R, Gerard Caprio, and Ross Levine, 2006. Rethinking Bank Regulation: Till Angels Govern. Cambridge: Cambridge University Press.

Barth, James R, Gerard Caprio, and Ross Levine, 2008. Bank Regulations Are Changing: For Better or Worse?. World Bank Policy Research Working Paper 4646,

Beck, Thorsten, Asli Demirgüç-Kunt and Ross Levine, 2000. A New Database on Financial

Development and Structure, World Bank Economic Review 14, 597-605.

Beck, Thorsten, Asli Demirgüç-Kunt, and Ross Levine, 2003, Law, endowment and finance, Journal of Financial Economics 70, 137-181.

Beck, Thorsten, Asli Demirgüç-Kunt, and Ross Levine, 2006, Bank supervision and corruption in lending, Journal of Monetary Economics 53, 2131-2163.

Beck, Thorsten, Ross Levine and Alexey Levkov, 2010, Big Bad Banks? The Winners and Losers from Bank Deregulation in the United States, Journal of Finance 65, 1637-1667.

Bekaert, Geert, Campbell R. Harvey, Christian Lundblad, 2001. Emerging equity markets and economic development, Journal of Development Economics 66, 465-504.

Bekaert, Geert, Campbell R. Harvey, Christian Lundblad, 2005. Does financial liberalization spur growth? Journal of Financial Economics 77, 3-55.

Bekaert, Geert, Campbell R. Harvey, Christian Lundblad, and Stephan Siegel, 2007. Global growth opportunities and market integration, Journal of Finance 62, 1081-1137. 
BIS, 2003. Guide to International Banking Statistics. BIS Papers No. 16, Monetary and Economic Department, Bank for International Settlements, Basle, April.

BIS, 2008a. The consolidated banking statistics: Foreign claims by nationality of reporting banks. Database on the website of the Bank for International Settlements: www.bis.org.

BIS, 2008b. Guidelines to the international locational banking statistics, Monetary and Economic Department, Bank for International Settlements, Basle, December.

BIS, 2010, Basel Committee on Banking Supervision - Report and Recommendations of the Cross-Border Bank Resolution Group.

Buch, Claudia, 2003, Information or Regulation: What Drives the International Activities of Commercial Banks? Journal of Money, Credit, and Banking 35, 851-869.

Dell'Ariccia, Giovanni, and Robert Marquez, 2010. Risk and the Corporate Structure of Banks, Journal of Finance, forthcoming.

Demirgüç-Kunt, Asli, and Enrica Detragiache, 2002. Does deposit insurance increase banking system stability? An empirical investigation. Journal of Monetary Economics 49, 1373-1406.

Djankov, Simeon, Rafael La Porta, Florencio Lopez-de-Silanes, and Andrei Shleifer. 2003 Courts. Quarterly Journal of Economics 118, 457-522.

Djankov, S., C. McLeish, A. Shleifer, 2007. Private credit in 129 countries, Journal of Financial Economics 84, 299-329.

Easterly, William, and Ross Levine. 1997. Africa's Growth Tragedy: Policies and Ethnic Divisions, Quarterly Journal of Economics 112(4), 1203-1250.

Feldstein, Martin, and Charles Horioka, 1980. Domestic Savings and International Capital Flows, Economic Journal 90, 314-329.

Fernandes, Nuno, Ugor Lei and Darius Mille, 2010. Escape from New York: The market impact of loosening disclosure requirements, Journal of Financial Economics 95, 129-147

Focarelli, Dario and Pozzolo, Alberto F., 2005. Where Do Banks Expand Abroad? An Empirical Analysis, Journal of Business 79, 2435-2463.

Gelos, Gaston, and Shang-jin Wei, 2005, Transparency and International Portfolio Holdings, Journal of Finance 60, 2987-3020.

Goodhardt, Charles, 2000, The organizational structure of banking supervision, BIS working paper.

Houston, Joel, Chen Lin, Ping Lin and Yue Ma, 2010, Creditor Rights, Information Sharing and Bank Risk Taking, Journal of Financial Economics, 96, 485-512.

International Monetary Fund (IMF) Staff Paper, 2010, Resolution of Cross-Border Banks - A Proposed Framework for Enhanced Coordination (Prepared by the Legal and Monetary and Capital Markets Departments, approved by Sean Hagan and José Viñals)

Jappelli, Tullio, and Marco Pagano, 2002, Information sharing, lending and defaults: Cross-country evidence, Journal of Banking and Finance 26, 2017-2045. 
King, Robert and Ross Levine, 1993. Finance and Growth: Schumpeter Might Be Right. Quarterly Journal of Economics, 717-738.

Knight, Malcolm, 2009. Rebuilding the Global Architecture of Financial Regulation, Vice Chairman of Deutsche Bank Global Group, speech made at University of Chicago Booth School of Business, http://research.chicagobooth.edu/igm/events/speaker-series/2009-04-01.aspx

Kraay, Aart, and Jaume Ventura, 2000. Current accounts in debtor and creditor countries. Quarterly Journal of Economics 115, 1137-1166.

La Porta, R., Lopez de Silanes, F., Shleifer, A., Vishny, R., 1998, Law and finance, Journal of Political Economy 106, 1113-1155.

La Porta, R., Lopez de Silanes, F., Shleifer, A., Vishny, R., 1999, The quality of government, Journal of Law, Economics, and Organization 15, 222-279.

La Porta, R., Lopez de Silanes, F., Shleifer, A., 2002. Government ownership of banks, Journal of Finance 57, 265-301.

Laeven, L. and Levine R., 2009. Bank governance, regulation and risk taking, Journal of Financial Economics 93, 259-275.

Lannoo, Karel, 2009. The Road Ahead After De Larosière, Brussels: Center for Economic Policy Studies, Policy Brief No. 195.

Levine, Ross and Sara Zervos, 1998. Stock Markets, Banks, and Economic Growth, American Economic Review 88, 537-558.

Lin, Chen, Yue Ma, Paul Malatesta, Yuhai Xuan, 2011a. Ownership structure and the cost of corporate borrowing. Journal of Financial Economics 100, 1-23.

Lin, Chen, Yue Ma, Paul Malatesta, Yuhai Xuan, 2011b. Corporate ownership structure and bank loan syndicate structure. Journal of Financial Economics, forthcoming.

Lucas, Robert, 1990, Why doesn't Capital Flow from Rich to Poor Countries?, American Economic Review 80, 92-96.

Marshall, Monty G., and Keith Jaggers, 2009. Polity IV Project, George Mason University and Center for Systemic Peace, www.systemicpeace.org/polity

McGuire, Patrick, and Nikola Tarashev, 2008, Global monitoring with the BIS international banking statistics, BIS working papers, No 224.

Mian, Atif, 2006, Distance constraints: The limits of foreign lending in poor economies, Journal of Finance 61, 1465-1505.

Morrison, Alan D., and Lucy White, 2009, Level Playing Fields in International Financial Regulation, Journal of Finance 64, 1099-1142.

Obstfeld, Maurice, and Kenneth Rogoff, 1995. The Intertemporal Approach to the Current Account, in Gene Grossman and Kenneth Rogoff (eds.) Handbook of International Economics, Amsterdam: Elsevier, 
Pang, Jiaren, Spindt, Paul and Sheri Tice, 2010, Diversification and internal Information Sharing: Evidence from Financial Conglomeration, Working Paper, Tulane University.

Papaioannou, Elias, 2009, What Drives International Financial Flows? Politics, Institutions and Other Determinants, Journal of Development Economics 88, 269-281.

Petersen, Mitchell, 2009, Estimating Standard Errors in Finance Panel Data Sets: Comparing Approaches, Review of Financial Studies, 22 (1); 435-480.

Prasad, Eswar, Raghuram Rajan and Arvind Subramanian, 2007, Foreign Capital and Economic Growth, Brookings Papers on Economic Activity, 153-209.

Rajan, Raghuram, 2008, Global Imbalances or Why are the Poor Financing the Rich, De Economist 156, 3-24.

Rajan, Raghuram and Arvind Subramanian, 2008, Aid and Growth: What does the Cross-Country Evidence Really Show?, Review of Economics and Statistics 90, 643-665.

Rajan, Raghuram, and Luigi Zingales 1998. Financial dependence and growth, American Economic Review 88, 559-586.

Rose, Andrew K., 2004. Do We Really Know That the WTO Increases Trade?. American Economic Review 94, 98-114.

Sachs, Jeffrey, 1981. The Current Account and Macroeconomic Adjustment in the 1970s, Brookings Papers on Economic Activity 1, 201-268.

Sengupta, Rajdeep, 2007, Foreign entry and bank competition, Journal of Financial Economics 84, 502-528.

Stulz, Rene M. and Rohan Williamson, 2003, Culture, openness, and finance, Journal of Financial Economics 70, 313-349.

Tesar, Linda, 1991. Savings, Investment and International Capital Flows, Journal of International Economics 31, 55-78.

Wooldridge, Philip D., 2002. Uses of the BIS statistics: An introduction. BIS Quarterly Review, Bank for International Settlements, Basle, March. 
Table 1. Variable definitions and data sources

\begin{tabular}{|c|c|c|}
\hline Variable & Definition & Original Sources \\
\hline Bank flows & $\begin{array}{l}\text { This variable captures the bank capital inflows from banks located in source country } s \text { to all sectors of the economy in } \\
\text { recipient country } r \text { from year } t-1 \text { to } t \text {. Specifically, it is defined as } 100 \text { times the log difference (i.e. difference in log } \\
\text { from } t-1 \text { to } t \text { ) of total foreign claims (FCsr) from source country } s \text { to recipient country } r \text {, that is, } 100 * \Delta \ln (F C s r) \text {. The } \\
\text { definition of foreign claims is defined by the nationality of the headquarter of the reporting bank published in the } \\
\text { consolidated banking statistics Table 9B in each issue of the BIS Quarterly Review. }\end{array}$ & $\begin{array}{l}\text { Bank for International } \\
\text { Settlements (BIS, } \\
\text { 2008a) }\end{array}$ \\
\hline Creditor rights & $\begin{array}{l}\text { An index aggregating creditor rights. Specifically, it measures (1) whether there are restrictions imposed, such as } \\
\text { creditors' consent or minimum dividend, when a debtor files for reorganization (Restrictions on Reorganization); ( } 2 \text { ) } \\
\text { whether secured creditors are able to gain possession of assets after the petition for reorganization is approved, that is, } \\
\text { whether there is no automatic stay or asset freeze imposed by the court on creditor's ability to seize collateral (No } \\
\text { Automatic Stay); (3) whether secured creditors are ranked first in the distribution of proceeds of liquidating a bankrupt } \\
\text { firm as opposed to other creditors such as government or workers (Secured Creditor Paid First); and (4) whether the } \\
\text { incumbent management does not stay in control of the firm during the reorganization (No Management Stay). The } \\
\text { index ranges between } 0 \text { and } 4 \text { and is constructed on yearly base. }\end{array}$ & $\begin{array}{l}\text { La Porta et al. (1998), } \\
\text { Djankov, et al (2007) }\end{array}$ \\
\hline $\begin{array}{l}\text { Depth of credit } \\
\text { information }\end{array}$ & $\begin{array}{l}\text { An index that measures the information contents of the credit information. A value of one is added to the index when a } \\
\text { country's information agencies have each of these characteristics: (1) both positive credit information (for example, } \\
\text { loan amounts and pattern of on-time repayments) and negative information (for example, late payments, number and } \\
\text { amount of defaults and bankruptcies) are distributed; (2) data on both firms and individual borrowers are distributed; } \\
\text { (3) data from retailers, trade creditors, or utilities, as well as from financial institutions, are distributed; (4) more than } 2 \\
\text { years of historical data are distributed; (5) data are collected on all loans of value above } 1 \% \text { of income per capita; and } \\
\text { (6) laws provide for borrowers' right to inspect their own data. The index ranges from } 0 \text { to } 6 \text {, with higher values } \\
\text { indicating the availability of more credit information, from either a public registry or a private bureau, to facilitate } \\
\text { lending decisions. If a country has no public registry or private bureau in a specific year, the index takes on the value } 0 \text {. } \\
\text { If an information agency exists in a country, the index takes on the value in that year or the value in the earliest } \\
\text { available year. }\end{array}$ & $\begin{array}{l}\text { Djankov et al. (2007), } \\
\text { World Bank "Doing } \\
\text { Business" database }\end{array}$ \\
\hline $\begin{array}{l}\text { Top } 5 \text { bank concentration } \\
\text { (all banks) }\end{array}$ & The fraction of total assets held by the five largest banks in the country. & Bankscope \\
\hline $\begin{array}{l}\text { Government bank } \\
\text { ownership }\end{array}$ & The fraction of the banking system's assets in the banks that are 50 percent or more owned by government. & $\begin{array}{l}\text { Barth et al. (2006, } \\
\text { 2008) }\end{array}$ \\
\hline $\begin{array}{l}\text { Overall activities } \\
\text { restrictions }\end{array}$ & $\begin{array}{l}\text { The extent to which banks may engage in (a) underwriting, brokering and dealing in securities, and all aspects of the } \\
\text { mutual fund industry, (b) insurance underwriting and selling, and (c) real estate investment, development, and } \\
\text { management. Unrestricted=1: full range of activities can be conducted directly in the bank; Permitted=2: full range of } \\
\text { activates can be conducted, but some or all must be conducted in subsidiaries; Restricted=3: less than full range of } \\
\text { activities can be conducted in the bank or subsidiaries; and Prohibited=4: the activity cannot be conducted in either the } \\
\text { bank or subsidiaries. Higher values indicate greater restrictiveness. }\end{array}$ & $\begin{array}{l}\text { Barth et al. (2006, } \\
\text { 2008) }\end{array}$ \\
\hline
\end{tabular}




\begin{tabular}{|c|c|c|}
\hline $\begin{array}{l}\text { Restriction on banks own } \\
\text { nonfinancial firms }\end{array}$ & $\begin{array}{l}\text { The extent to which banks may own and control nonfinancial firms (higher value means more restrictive). } \\
\text { Unrestricted=1=a bank may own } 100 \text { percent of the equity in any nonfinancial firm; } \\
\text { Permitted=2=a bank may own } 100 \text { percent of the equity of a nonfinancial firm, but ownership is limited based on a } \\
\text { bank's equity capital; } \\
\text { Restricted=3=a bank can only acquire less than } 100 \text { percent of the equity in a nonfinancial firm; and } \\
\text { Prohibited=4=a bank may not acquire any equity investment in a nonfinancial firm whatsoever. }\end{array}$ & $\begin{array}{l}\text { Barth et al. (2006, } \\
\text { 2008) }\end{array}$ \\
\hline $\begin{array}{l}\text { Independence of } \\
\text { supervisory authority - } \\
\text { Overall }\end{array}$ & $\begin{array}{l}\text { The degree to which the supervisory authority is independent from the government and legally protected from the } \\
\text { banking industry. The indicator is constructed based on the following three questions. 1. Are the supervisory bodies } \\
\text { responsible or accountable to a) Prime Minister, b) the Finance Minister or other cabinet level official, c) a legislative } \\
\text { body, such as parliament of congress (yes=1)? 2. Are the supervisors legally liable for their actions (i.e. if a } \\
\text { supervisor takes actions against a bank, the supervisor cannot be sued) }(\mathrm{No}=1) \text { ? 3. Does the head of the supervisory } \\
\text { agency (and other directors) have a fixed term and how long? ( }=1 \text { if the term }>=4) \text {. Higher value means a more } \\
\text { independent supervisory agency. }\end{array}$ & $\begin{array}{l}\text { Barth et al. (2006, } \\
\text { 2008) }\end{array}$ \\
\hline Official supervisory power & $\begin{array}{l}\text { Principal component indicator of } 14 \text { dummy variables: 1.Does the supervisory agency have the right to meet with } \\
\text { external auditors to discuss their report without the approval of the bank? 2.Are auditors required by law to } \\
\text { communicate directly to the supervisory agency any presumed involvement of bank directors or senior managers in } \\
\text { elicit activities, fraud, or insider abuse? 3. Can supervisors take legal action against external auditors for negligence? } \\
\text { 4.Can the supervisory authority force a bank to change its internal organizational structure? } 5 \text {. Are off-balance sheet } \\
\text { items disclosed to supervisors? 6. Can the supervisory agency order the bank's directors or management to constitute } \\
\text { provisions to cover actual or potential losses? 7. Can the supervisory agency suspend the directors' decision to } \\
\text { distribute: a) Dividends? b) Bonuses? c) Management fees? 8. Can the supervisory agency legally declare-such that } \\
\text { this declaration supersedes the rights of bank shareholders-that a bank is insolvent? 9. Does the Banking Law give } \\
\text { authority to the supervisory agency to intervene that is, suspend some or all ownership rights-a problem bank? } \\
\text { 10.Regarding bank restructuring and reorganization, can the supervisory agency } \\
\text { or any other government agency do the following: a) Supersede shareholder rights? b) Remove and replace } \\
\text { management? c) Remove and replace directors? }\end{array}$ & $\begin{array}{l}\text { Barth et al. (2006, } \\
\text { 2008) }\end{array}$ \\
\hline $\begin{array}{l}\text { Loan classification } \\
\text { leniency }\end{array}$ & $\begin{array}{l}\text { If there is a loan classification system, the actual minimum number of days beyond which a loan in arrears must be } \\
\text { classified as substandard, then doubtful, and finally loss are summed. Higher values indicate less stringency. }\end{array}$ & $\begin{array}{l}\text { Barth et al. (2006, } \\
\text { 2008) }\end{array}$ \\
\hline $\begin{array}{l}\text { Capital regulatory index } \\
\text { (total) }\end{array}$ & $\begin{array}{l}\text { The sum of overall capital regulatory stringency and initial capital stringency, which measures whether certain funds } \\
\text { may be used to initially capitalize a bank and whether they are officially verified. Higher values indicate greater } \\
\text { stringency. }\end{array}$ & $\begin{array}{l}\text { Barth et al. (2006, } \\
2008)\end{array}$ \\
\hline Strength of external audit & $\begin{array}{l}\text { The effectiveness of external audits of banks. It is an indicator developed based on the following } \\
\text { questions (Yes }=1, \mathrm{No}=0 \text { ) : } 1 \text {. Is an external audit a compulsory obligation for banks? 2. Are specific requirements for } \\
\text { the extent or nature of the audit spelled out? } 3 \text {. Are auditors licensed or certified? } 4 \text {. Do supervisors get a copy of the } \\
\text { auditor's report? } 5 \text {. Does the supervisory agency have the right to meet with external auditors to discuss their report } \\
\text { without the approval of the bank? } 6 \text {. Are auditors required by law to communicate directly to the supervisory agency }\end{array}$ & $\begin{array}{l}\text { Barth et al. (2006, } \\
2008)\end{array}$ \\
\hline
\end{tabular}




\begin{tabular}{|c|c|c|}
\hline & $\begin{array}{l}\text { any presumed involvement of bank directors or senior managers in illicit activities, fraud, or insider abuse? } 7 . \text { Can } \\
\text { supervisors take legal action against external auditors for negligence? Higher values indicate better strength of external } \\
\text { audit. }\end{array}$ & \\
\hline $\begin{array}{l}\text { Financial statement } \\
\text { transparency }\end{array}$ & $\begin{array}{l}\text { It includes the information on whether accrued, though unpaid, interest/principal enter the income statement; whether } \\
\text { financial institutions are required to produce consolidated accounts covering all bank and any non-bank financial } \\
\text { subsidiaries; whether off-balance sheet items are disclosed to the public; whether banks are required to disclose their } \\
\text { risk management procedures to the public; and whether bank directors are legally liable if information disclosed is } \\
\text { erroneous or misleading. The index ranges from } 0 \text { to } 6 \text { with higher values indicating better financial statement } \\
\text { transparency. }\end{array}$ & $\begin{array}{l}\text { Barth et al. (2006, } \\
2008)\end{array}$ \\
\hline $\begin{array}{l}\text { No. of days to enforce } \\
\text { contracts }\end{array}$ & $\begin{array}{l}\text { Number of calendar days counted from the moment the plaintiff files the lawsuit in court until payment. This includes } \\
\text { both the days when actions take place and the waiting periods between. The respondents make separate estimates of } \\
\text { the average duration of different stages of dispute resolution: the completion of service of process (time to file the } \\
\text { case), the issuance of judgment (time for the trial and obtaining the judgment) and the moment of payment (time for } \\
\text { enforcement). }\end{array}$ & $\begin{array}{l}\text { Djankov et al. (2003), } \\
\text { World Bank “Doing } \\
\text { Business” database }\end{array}$ \\
\hline Property rights & $\begin{array}{l}\text { Countries with more secure property rights and legal institutions that were more supportive of rule of law received } \\
\text { higher ratings. }\end{array}$ & $\begin{array}{l}\text { Fraser Institute Website } \\
\text { (2008) }\end{array}$ \\
\hline Log income & Log real GDP per capita, in UD dollars. & $\begin{array}{l}\text { World Development } \\
\text { Indicators (WDI) }\end{array}$ \\
\hline Log population & Log population (millions) & $\begin{array}{l}\text { World Development } \\
\text { Indicators (WDI) }\end{array}$ \\
\hline Common language & Dummy variable that equals one if the two countries share a common language & Rose (2004) \\
\hline Log distance & Log geographic distance & $\begin{array}{l}\text { World Development } \\
\text { Indicators (WDI) }\end{array}$ \\
\hline $\begin{array}{l}\text { Financial liberalization } \\
\text { index }\end{array}$ & $\begin{array}{l}\text { An index of financial liberalization over the period of } 1973-2005 \text { for } 91 \text { economies. Codes were assigned along the } \\
\text { seven dimensions below. Each dimension has various sub-dimensions. Based on the score for each sub-dimension, } \\
\text { each dimension receives a "raw score." The explanations for each sub-dimension below indicate how to assign the raw } \\
\text { score. After a raw score is assigned, it is normalized to a } 0-3 \text { scale. The normalization is done on the basis of the } \\
\text { classifications listed below for each dimension. That is, fully liberalized=3; partially liberalized=2; partially } \\
\text { repressed=1; fully repressed=0. The index contains various dimensions including credit controls and reserve } \\
\text { requirements, interest rate liberalization, entry barriers, capital account restrictions, privatization, and securities market } \\
\text { policies and supervision. }\end{array}$ & Abiad, et al. (2010) \\
\hline Growth opportunity & $\begin{array}{l}\text { An implied measure of country-specific growth opportunities that reflects the growth prospects for each industry (at } \\
\text { the global level) weighted by the industrial composition for each country. An annual measure is constructed as the } \\
\text { 3-digit SIC industry composition for each country by their output shares according to UNIDO Industrial Statistics }\end{array}$ & $\begin{array}{l}\text { Bekaert, et al. (2007), } \\
\text { Datastream, and }\end{array}$ \\
\hline
\end{tabular}




\begin{tabular}{|c|c|c|}
\hline & 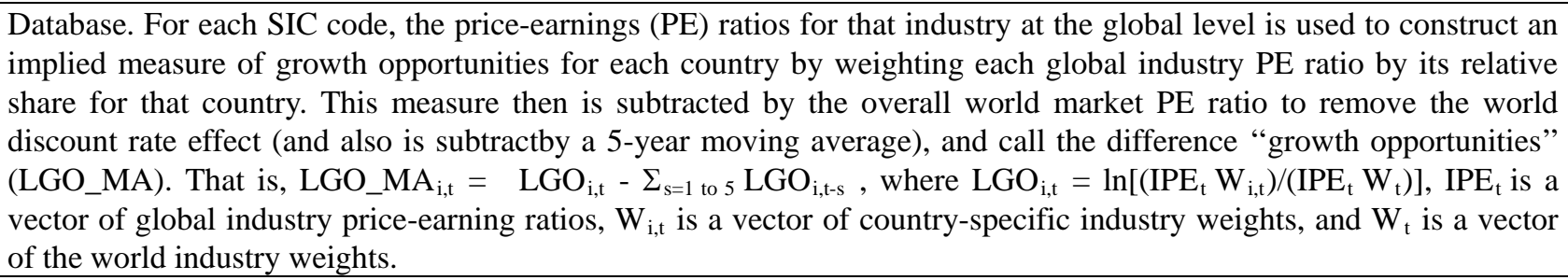 & $\begin{array}{l}\text { UNIDO Industrial } \\
\text { Statistics Database }\end{array}$ \\
\hline Current account /GNP (\%) & The current account divided by GNP (\%) & $\begin{array}{l}\text { World Development } \\
\text { Indicators (WDI) }\end{array}$ \\
\hline Saving /GNP (\%) & The gross saving of both the public and private sectors divided by GNP (\%) & $\begin{array}{l}\text { World Development } \\
\text { Indicators (WDI) }\end{array}$ \\
\hline Foreign subsidiary dummy & $\begin{array}{l}\text { A dummy that takes the value of one if the bank with headquarter in country } s \text { has a foreign subsidiary in country } r \text {, } \\
\text { and is zero otherwise, in } 2008 \text {. }\end{array}$ & Bankscope \\
\hline $\begin{array}{l}\text { Foreign branch/subsidiary } \\
\text { dummy }\end{array}$ & $\begin{array}{l}\text { A dummy that takes the value of one if the bank with headquarter in country } s \text { has either a foreign subsidiary or a } \\
\text { foreign branch in country } r \text {, and is zero otherwise, in } 2008 \text {. }\end{array}$ & Bankscope \\
\hline Bank size & Log of bank total assets (thousands of USD), 3-year average over 2005-2007. & Bankscope \\
\hline Bank net income & Bank’s net income divided by total assets (\%), 3-year average over 2005-2007. & Bankscope \\
\hline
\end{tabular}


Table 2. Summary statistics

\begin{tabular}{|c|c|c|c|c|c|c|c|}
\hline Variable & Mean & Median & Std.Dev. & Min & Max & Obs & $\begin{array}{c}\text { No. of } \\
\text { countries }\end{array}$ \\
\hline \multicolumn{8}{|l|}{ Panel A: Bilateral relation variables } \\
\hline Bank flows & 2.89 & 2.03 & 11.32 & -99.97 & 99.98 & 24,233 & 120 \\
\hline Common language & 0.14 & 0 & 0.35 & 0 & 1 & 2,065 & 120 \\
\hline Log distance & 8.03 & 8.33 & 0.92 & 4.80 & 9.90 & 2,065 & 120 \\
\hline \multicolumn{8}{|l|}{ Panel B: Country level variables } \\
\hline Creditor rights & 1.81 & 2 & 1.13 & 0 & 4 & 1368 & 120 \\
\hline Depth of credit information & 3.06 & 3 & 2.21 & 0 & 6 & & 120 \\
\hline Top 5 bank concentration & 0.80 & 0.83 & 0.18 & 0.19 & 1 & 1368 & 120 \\
\hline Government bank ownership & 0.20 & 0.12 & 0.24 & 0 & 0.94 & 1272 & 113 \\
\hline No. of days to enforce contracts (log) & 6.39 & 6.24 & 5.65 & 4.79 & 7.29 & 1368 & 120 \\
\hline Property rights & 5.37 & 5.30 & 1.77 & 1.43 & 9.62 & 1368 & 120 \\
\hline Log income & 7.50 & 7.43 & 1.59 & 4.41 & 10.63 & 1368 & 120 \\
\hline Log population & 2.66 & 2.39 & 1.35 & 0.47 & 7.19 & 1368 & 120 \\
\hline Financial liberalization index & 15.31 & 15.25 & 3.73 & 3.75 & 21.00 & 792 & 86 \\
\hline Growth opportunity & 0.01 & 0.01 & 0.09 & -0.33 & 0.33 & 1059 & 92 \\
\hline Current account /GNP (\%) & -2.28 & -2.65 & 8.20 & -44.73 & 55.53 & 1,202 & 104 \\
\hline Saving /GNP (\%) & 19.72 & 18.83 & 9.07 & 0.41 & 58.36 & 1,202 & 104 \\
\hline \multicolumn{8}{|l|}{ Panel C: Regulatory variables } \\
\hline Overall activities restrictions & 7.64 & 8 & 2.03 & 3 & 12 & 1272 & 113 \\
\hline Restriction on banks own nonfinancial firms & 2.57 & 3 & 0.79 & 1 & 4 & 1272 & 113 \\
\hline Capital regulatory index (total) & 6.00 & 6 & 1.78 & 1 & 10 & 1260 & 111 \\
\hline Independence of supervisory authority - overall & 1.70 & 2 & 0.89 & 0 & 3 & 1236 & 109 \\
\hline Official Supervisory Power & 11.16 & 11 & 2.44 & 4 & 16 & 1296 & 114 \\
\hline Loan classification leniency (log) & 7.18 & 6.70 & 1.29 & 3.40 & 9.30 & 1296 & 114 \\
\hline Strength of external audit & 5.19 & 6 & 1.19 & 2 & 7 & 1272 & 113 \\
\hline Financial statement transparency & 4.01 & 5 & 0.97 & 1 & 6 & 1224 & 108 \\
\hline $\begin{array}{l}\text { Panel D: Cross-section data for banks' foreign } \\
\text { affiliates }\end{array}$ & & & & & & & $\begin{array}{l}\text { No. of } \\
\text { banks }\end{array}$ \\
\hline \multicolumn{8}{|l|}{ Bank level variables } \\
\hline Foreign subsidiary dummy & 0.06 & 0 & 0.22 & 0 & 1 & 35,819 & 301 \\
\hline Foreign branch/subsidiary dummy & 0.07 & 0 & 0.23 & 0 & 1 & 35,819 & 301 \\
\hline Bank size & 18.67 & 18.44 & 1.27 & 17.04 & 21.62 & 35,819 & 301 \\
\hline Bank net income & 0.91 & 0.76 & 0.93 & -0.487 & 8.90 & 35,819 & 301 \\
\hline
\end{tabular}

Note: For Panel A, B, and C, the sample period is 1996-2007. For Panel D, the sample is for 2007/8. 
Table 3A. Regulatory arbitrage and aggregate bank inflows

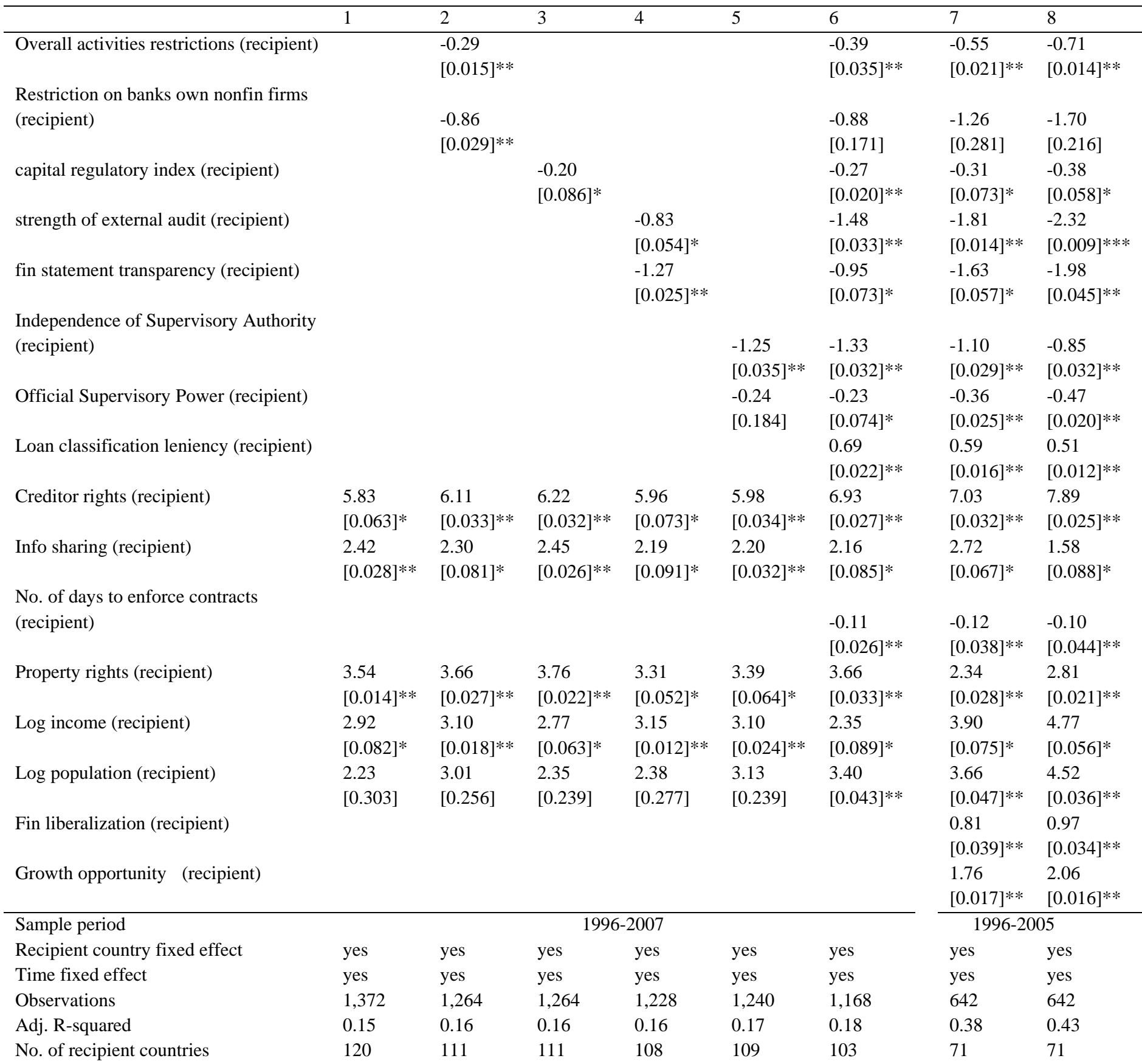

Note: The dependent variable is aggregate bank inflows to 120 recipient countries, which is defined as 100 times the log-difference of total foreign claims $(F C r)$ of 26 source countries to recipient country $r$, that is, $100^{*} \Delta \ln (\Sigma s F C s r)$. The estimation is based on fixed effect OLS regressions. For column 8, it is based on GDP (in US \$)-weighted OLS estimation. The country level banking regulatory variables are time varying and are based on three major surveys spanning almost over a decade by the World Bank (Barth, Caprio, and Levine, 2008). The values of regulatory variables for the period of 1996 to 1999 are taken from the first survey recorded in 1998/1999. Their values for the period of 2000 to 2003 are taken from the second survey that assesses the state of regulation as of the end of 2002. Their values for the period of 2004 to 2007 are taken from the third survey that was sought a characterization of the environment as of the end of 2005. Detailed variable definitions can be found in Table 1. Time fixed effects and recipient country specific effects are included in the regressions but not reported. P-values are computed by the heteroskedasticity-robust standard errors clustered for recipient countries and are presented in brackets. *,**,*** represent statistical significance at the $10 \%, 5 \%$ and $1 \%$ level respectively. 
Table 3B. Regulatory arbitrage and aggregate bank outflows

\begin{tabular}{|c|c|c|c|c|c|c|c|c|}
\hline \multirow{2}{*}{ Overall activities restrictions (source) } & 1 & 2 & 3 & 4 & 5 & 6 & 7 & 8 \\
\hline & & $\begin{array}{l}0.53 \\
{[0.025]^{* *}}\end{array}$ & & & & $\begin{array}{l}0.92 \\
{[0.024] * *}\end{array}$ & $\begin{array}{l}1.06 \\
{[0.017]^{* *}}\end{array}$ & $\begin{array}{l}1.16 \\
{[0.012]^{* *}}\end{array}$ \\
\hline \multirow{2}{*}{$\begin{array}{l}\text { Restriction on banks own nonfin firms } \\
\text { (source) }\end{array}$} & & & & & & & & \\
\hline & & $\begin{array}{l}2.33 \\
{[0.087]^{*}}\end{array}$ & & & & $\begin{array}{l}2.28 \\
{[0.017]^{* *}}\end{array}$ & $\begin{array}{l}2.19 \\
{[0.014]^{* *}}\end{array}$ & $\begin{array}{l}1.50 \\
{[0.017]^{* *}}\end{array}$ \\
\hline capital regulatory index (source) & & & $\begin{array}{l}0.28 \\
{[0.038]^{* *}}\end{array}$ & & & $\begin{array}{l}0.41 \\
{[0.097]^{*}}\end{array}$ & $\begin{array}{l}0.65 \\
{[0.076]^{*}}\end{array}$ & $\begin{array}{l}0.78 \\
{[0.057]^{*}}\end{array}$ \\
\hline strength of external audit (source) & & & & $\begin{array}{l}0.85 \\
{[0.032]^{* *}}\end{array}$ & & $\begin{array}{l}0.74 \\
{[0.218]}\end{array}$ & $\begin{array}{l}1.27 \\
{[0.139]}\end{array}$ & $\begin{array}{l}1.72 \\
{[0.113]}\end{array}$ \\
\hline fin statement transparency (source) & & & & $\begin{array}{l}2.62 \\
{[0.026]^{* *}}\end{array}$ & & $\begin{array}{l}2.74 \\
{[0.030]^{* *}}\end{array}$ & $\begin{array}{l}2.45 \\
{[0.026]^{* *}}\end{array}$ & $\begin{array}{l}2.91 \\
{[0.021]^{* *}}\end{array}$ \\
\hline \multirow{2}{*}{$\begin{array}{l}\text { Independence of Supervisory Authority } \\
\text { (source) }\end{array}$} & & & & & & & & \\
\hline & & & & & $\begin{array}{l}1.05 \\
{[0.083]^{*}}\end{array}$ & $\begin{array}{l}1.41 \\
{[0.542]}\end{array}$ & $\begin{array}{l}1.89 \\
{[0.389]}\end{array}$ & $\begin{array}{l}1.26 \\
{[0.446]}\end{array}$ \\
\hline Official Supervisory Power (source) & & & & & $\begin{array}{l}1.83 \\
{[0.131]}\end{array}$ & $\begin{array}{l}1.76 \\
{[0.041]^{* *}}\end{array}$ & $\begin{array}{l}1.28 \\
{[0.037]^{* *}}\end{array}$ & $\begin{array}{l}0.78 \\
{[0.059]^{*}}\end{array}$ \\
\hline Loan classification leniency (source) & & & & & & $\begin{array}{l}-0.44 \\
{[0.013]^{* *}}\end{array}$ & $\begin{array}{l}-0.32 \\
{[0.018]^{* *}}\end{array}$ & $\begin{array}{l}-0.25 \\
{[0.025]^{* *}}\end{array}$ \\
\hline Creditor rights (source) & $\begin{array}{l}-3.24 \\
{[0.016]^{* *}}\end{array}$ & $\begin{array}{l}-3.86 \\
{[0.022] * *}\end{array}$ & $\begin{array}{l}-3.31 \\
{[0.052]^{*}}\end{array}$ & $\begin{array}{l}-2.95 \\
{[0.141]}\end{array}$ & $\begin{array}{l}-2.90 \\
{[0.113]}\end{array}$ & $\begin{array}{l}-2.89 \\
{[0.024]^{* *}}\end{array}$ & $\begin{array}{l}-2.77 \\
{[0.034]^{* *}}\end{array}$ & $\begin{array}{l}-3.09 \\
{[0.026]^{* *}}\end{array}$ \\
\hline Info sharing (source) & $\begin{array}{l}-1.55 \\
{[0.028]^{* *}}\end{array}$ & $\begin{array}{l}-1.18 \\
{[0.030]^{* *}}\end{array}$ & $\begin{array}{l}-1.56 \\
{[0.028]^{* *}}\end{array}$ & $\begin{array}{l}-1.08 \\
{[0.030]^{* *}}\end{array}$ & $\begin{array}{l}-0.84 \\
{[0.173]}\end{array}$ & $\begin{array}{l}-0.76 \\
{[0.003]^{* * *}}\end{array}$ & $\begin{array}{l}-0.97 \\
{[0.015]^{* *}}\end{array}$ & $\begin{array}{l}-0.70 \\
{[0.0061]^{* * *}}\end{array}$ \\
\hline No. of days to enforce contracts (source) & & & & & & $\begin{array}{l}0.21 \\
{[0.014]^{* *}}\end{array}$ & $\begin{array}{l}0.19 \\
{[0.017]^{* *}}\end{array}$ & $\begin{array}{l}0.22 \\
{[0.016]^{* *}}\end{array}$ \\
\hline Property rights (source) & $\begin{array}{l}-4.61 \\
{[0.035]^{* *}}\end{array}$ & $\begin{array}{l}-4.26 \\
{[0.063]^{*}}\end{array}$ & $\begin{array}{l}-4.62 \\
{[0.058]^{*}}\end{array}$ & $\begin{array}{l}-4.36 \\
{[0.062]^{*}}\end{array}$ & $\begin{array}{l}-5.70 \\
{[0.037]^{* *}}\end{array}$ & $\begin{array}{l}-4.79 \\
{[0.035]^{* *}}\end{array}$ & $\begin{array}{l}-5.17 \\
{[0.024]^{* *}}\end{array}$ & $\begin{array}{l}-6.51 \\
{[0.018]^{* *}}\end{array}$ \\
\hline Log income (source) & $\begin{array}{l}-1.02 \\
{[0.333]}\end{array}$ & $\begin{array}{l}-1.70 \\
{[0.032]^{* *}}\end{array}$ & $\begin{array}{l}-1.56 \\
{[0.330]}\end{array}$ & $\begin{array}{l}-1.65 \\
{[0.281]}\end{array}$ & $\begin{array}{l}-1.74 \\
{[0.036]^{* *}}\end{array}$ & $\begin{array}{l}-1.31 \\
{[0.277]}\end{array}$ & $\begin{array}{l}-1.82 \\
{[0.145]}\end{array}$ & $\begin{array}{l}-2.09 \\
{[0.108]}\end{array}$ \\
\hline Log population (source) & $\begin{array}{l}-2.01 \\
{[0.122]}\end{array}$ & $\begin{array}{l}-2.68 \\
{[0.031]^{* *}}\end{array}$ & $\begin{array}{l}-2.13 \\
{[0.120]}\end{array}$ & $\begin{array}{l}-1.85 \\
{[0.124]}\end{array}$ & $\begin{array}{l}-2.53 \\
{[0.081]^{*}}\end{array}$ & $\begin{array}{l}-2.73 \\
{[0.146]}\end{array}$ & $\begin{array}{l}-2.98 \\
{[0.123]}\end{array}$ & $\begin{array}{l}-1.71 \\
{[0.149]}\end{array}$ \\
\hline Fin liberalization (source) & & & & & & & $\begin{array}{l}0.42 \\
{[0.176]}\end{array}$ & $\begin{array}{l}0.34 \\
{[0.228]}\end{array}$ \\
\hline Growth opportunity (source) & & & & & & & $\begin{array}{l}-1.49 \\
{[0.025]^{* *}}\end{array}$ & $\begin{array}{l}-1.26 \\
{[0.030]^{* *}}\end{array}$ \\
\hline Sample period & \multicolumn{6}{|c|}{ 1996-2007 } & \multicolumn{2}{|c|}{ 1996-2005 } \\
\hline Source country fixed effect & yes & yes & yes & yes & yes & yes & yes & yes \\
\hline Time fixed effect & yes & yes & yes & yes & yes & yes & yes & yes \\
\hline Observations & 238 & 238 & 238 & 238 & 238 & 238 & 181 & 181 \\
\hline Adj. R-squared & 0.30 & 0.31 & 0.32 & 0.30 & 0.32 & 0.36 & 0.37 & 0.41 \\
\hline No. of source countries & 26 & 26 & 26 & 26 & 26 & 26 & 23 & 23 \\
\hline
\end{tabular}

Note: The dependent variable is aggregate bank outflows from 26 source countries, which is defined as 100 times the log-difference of total foreign claims (FCs) of source country $s$ to 120 recipient countries, that is, $100 * \Delta \ln (\Sigma \mathrm{r} F C s r)$. The estimation is based on fixed effect OLS regressions. For column 8, it is based on GDP (in US \$)-weighted OLS estimation. The country level banking regulatory variables are time varying and are based on three major surveys spanning almost over a decade by the World Bank (Barth, Caprio, and Levine, 2008). The values of regulatory variables for the period of 1996 to 1999 are taken from the first survey recorded in 1998/1999. Their values for the period of 2000 to 2003 are taken from the second survey that assesses the state of regulation as of the end of 2002. Their values for the period of 2004 to 2007 are taken from the third survey that was sought a characterization of the environment as of the end of 2005. Detailed variable definitions can be found in Table 1. Time fixed effects and source country specific effects are included in the regressions but not reported. P-values are computed by the heteroskedasticity-robust standard errors clustered for source countries and are presented in brackets. *, **, *** represent statistical significance at the $10 \%, 5 \%$ and $1 \%$ level respectively. 
Table 4. Regulatory arbitrage and bank flows

\begin{tabular}{|c|c|c|c|c|c|c|c|c|}
\hline & 1 & 2 & 3 & 4 & 5 & 6 & 7 & 8 \\
\hline \multirow{2}{*}{$\begin{array}{l}\text { Overall activities restrictions } \\
\text { (source) }\end{array}$} & & 0.39 & & & & 0.30 & 0.36 & 0.29 \\
\hline & & {$[0.014]^{* *}$} & & & & {$[0.005]^{* * *}$} & {$[0.005]^{* * *}$} & {$[0.007]^{* * *}$} \\
\hline \multirow{2}{*}{$\begin{array}{l}\text { Overall activities restrictions } \\
\text { (recipient) }\end{array}$} & & -0.25 & & & & -0.32 & -0.33 & -0.27 \\
\hline & & {$[0.013]^{* *}$} & & & & {$[0.013]^{* *}$} & {$[0.011]^{* *}$} & {$[0.014]^{* *}$} \\
\hline \multirow[t]{2}{*}{$\begin{array}{l}\text { Restriction on banks own nonfin } \\
\text { firms (source) }\end{array}$} & & 1.30 & & & & 1.56 & 1.52 & 1.22 \\
\hline & & {$[0.071]^{*}$} & & & & {$[0.021]^{* *}$} & {$[0.020]^{* *}$} & {$[0.022]^{* *}$} \\
\hline \multirow{2}{*}{$\begin{array}{l}\text { Restriction on banks own nonfin } \\
\text { firms (recipient) }\end{array}$} & & -1.97 & & & & -1.41 & -1.42 & -1.75 \\
\hline & & {$[0.014]^{* *}$} & & & & [0.149] & [0.143] & {$[0.116]$} \\
\hline \multirow[t]{2}{*}{ capital regulatory index (source) } & & & 0.59 & & & 0.25 & 0.23 & 0.18 \\
\hline & & & {$[0.027]^{* *}$} & & & {$[0.081]^{*}$} & {$[0.078]^{*}$} & [0.103] \\
\hline \multirow{2}{*}{$\begin{array}{l}\text { capital regulatory index } \\
\text { (recipient) }\end{array}$} & & & -0.43 & & & -0.35 & -0.34 & -0.25 \\
\hline & & & {$[0.072]^{*}$} & & & {$[0.033]^{* *}$} & {$[0.026]^{* *}$} & {$[0.031]^{* *}$} \\
\hline \multirow[t]{2}{*}{ strength of external audit (source) } & & & & 0.72 & & 0.52 & 0.70 & 0.61 \\
\hline & & & & {$[0.028]^{* *}$} & & [0.158] & [0.153] & [0.169] \\
\hline \multirow{2}{*}{$\begin{array}{l}\text { strength of external audit } \\
\text { (recipient) }\end{array}$} & & & & -0.26 & & -0.47 & -0.65 & -0.53 \\
\hline & & & & {$[0.058]^{*}$} & & {$[0.030]^{* *}$} & {$[0.021]^{* *}$} & {$[0.029]^{* *}$} \\
\hline \multirow{2}{*}{$\begin{array}{l}\text { fin statement transparency } \\
\text { (source) }\end{array}$} & & & & 1.60 & & 1.28 & 1.85 & 1.40 \\
\hline & & & & {$[0.035]^{* *}$} & & {$[0.027]^{* *}$} & {$[0.020]^{* *}$} & {$[0.026]^{* *}$} \\
\hline \multirow[t]{2}{*}{$\begin{array}{l}\text { fin statement transparency } \\
\text { (recipient) }\end{array}$} & & & & -0.96 & & -0.59 & -0.56 & -0.75 \\
\hline & & & & {$[0.022]^{* *}$} & & {$[0.064]^{*}$} & {$[0.062]^{*}$} & {$[0.036]^{* *}$} \\
\hline \multirow[t]{2}{*}{$\begin{array}{l}\text { Independence of Supervisory } \\
\text { Authority (source) }\end{array}$} & & & & & 0.94 & 1.29 & 1.05 & 0.87 \\
\hline & & & & & {$[0.060]^{*}$} & {$[0.140]$} & [0.199] & {$[0.254]$} \\
\hline \multirow[t]{2}{*}{$\begin{array}{l}\text { Independence of Supervisory } \\
\text { Authority (recipient) }\end{array}$} & & & & & -0.71 & -0.55 & -0.83 & -0.68 \\
\hline & & & & & {$[0.040]^{* *}$} & {$[0.040]^{* *}$} & {$[0.030]^{* *}$} & {$[0.034]^{* *}$} \\
\hline \multirow[t]{2}{*}{$\begin{array}{l}\text { Official Supervisory Power } \\
\text { (source) }\end{array}$} & & & & & 0.46 & 0.61 & 0.66 & 0.57 \\
\hline & & & & & {$[0.036]^{* *}$} & {$[0.056]^{*}$} & {$[0.052]^{*}$} & {$[0.070]^{*}$} \\
\hline \multirow[t]{2}{*}{$\begin{array}{l}\text { Official Supervisory Power } \\
\text { (recipient) }\end{array}$} & & & & & -0.39 & -0.35 & -0.52 & -0.65 \\
\hline & & & & & {$[0.065]^{*}$} & {$[0.031]^{* *}$} & {$[0.021]^{* *}$} & {$[0.016]^{* *}$} \\
\hline \multirow{2}{*}{$\begin{array}{l}\text { Loan classification leniency } \\
\text { (source) }\end{array}$} & & & & & & -0.26 & -0.27 & -0.22 \\
\hline & & & & & & {$[0.002]^{* * *}$} & {$[0.004]^{* * *}$} & {$[0.005]^{* * *}$} \\
\hline \multirow[t]{2}{*}{$\begin{array}{l}\text { Loan classification leniency } \\
\text { (recipient) }\end{array}$} & & & & & & 0.43 & 0.41 & 0.33 \\
\hline & & & & & & {$[0.037]^{* *}$} & {$[0.033]^{* *}$} & {$[0.039]^{* *}$} \\
\hline \multirow[t]{2}{*}{ Creditor rights (source) } & -3.68 & -3.74 & -3.03 & -2.74 & -3.31 & -2.68 & -2.40 & -1.83 \\
\hline & {$[0.019]^{* *}$} & {$[0.014]^{* *}$} & {$[0.016]^{* *}$} & {$[0.059]^{*}$} & {$[0.096]^{*}$} & {$[0.026]^{* *}$} & {$[0.024]^{* *}$} & {$[0.034]^{* *}$} \\
\hline \multirow[t]{2}{*}{ Creditor rights (recipient) } & 4.69 & 4.56 & 3.94 & 4.18 & 4.59 & 3.39 & 3.65 & 2.94 \\
\hline & {$[0.018]^{* *}$} & {$[0.020]^{* *}$} & {$[0.070]^{*}$} & {$[0.036]^{* *}$} & {$[0.048]^{* *}$} & {$[0.018]^{* *}$} & {$[0.019]^{* *}$} & {$[0.024]^{* *}$} \\
\hline \multirow[t]{2}{*}{ Info sharing (source) } & -0.66 & -0.67 & -0.39 & -0.74 & -0.72 & -0.46 & -0.68 & -0.55 \\
\hline & {$[0.011]^{* *}$} & {$[0.018]^{* *}$} & {$[0.061]^{*}$} & {$[0.008]^{* * *}$} & {$[0.011]^{* *}$} & {$[0.045]^{* *}$} & {$[0.040]^{* *}$} & {$[0.063]^{*}$} \\
\hline \multirow[t]{2}{*}{ Info sharing (recipient) } & 0.85 & 1.11 & 1.01 & 1.15 & 0.93 & 1.12 & 1.17 & 1.26 \\
\hline & {$[0.074]^{*}$} & {$[0.021]^{* *}$} & {$[0.027]^{* *}$} & {$[0.020]^{* *}$} & {$[0.063]^{*}$} & {$[0.062]^{*}$} & {$[0.062]^{*}$} & {$[0.034]^{* *}$} \\
\hline \multirow[t]{2}{*}{$\begin{array}{l}\text { No. of days to enforce contracts } \\
\text { (recipient) }\end{array}$} & & & & & & 0.08 & 0.10 & 0.08 \\
\hline & & & & & & {$[0.030]^{* *}$} & {$[0.040]^{* *}$} & {$[0.057]^{*}$} \\
\hline \multirow[t]{2}{*}{$\begin{array}{l}\text { No. of days to enforce contracts } \\
\text { (source) }\end{array}$} & & & & & & -0.14 & -0.15 & -0.12 \\
\hline & & & & & & {$[0.014]^{* *}$} & {$[0.020]^{* *}$} & {$[0.024]^{* *}$} \\
\hline
\end{tabular}


Top 5 bank concentration

Government bank ownership (recipient)

Property rights (source)

Property rights (recipient)

Log income (source)

Log income (recipient)

Log population (source)

Log population (recipient)

Common language

Log distance

Fin liberalization (source)

Fin liberalization (recipient)

Growth opportunity (source)

Growth opportunity (recipient) (recipient)

\begin{tabular}{|c|c|c|}
\hline-2.60 & -3.64 & -2.96 \\
\hline$[0.092]^{*}$ & {$[0.062]^{*}$} & {$[0.075]^{*}$} \\
\hline-1.09 & -1.67 & -1.37 \\
\hline$[0.035]^{* *}$ & {$[0.030]^{* *}$} & {$[0.038]^{* *}$} \\
\hline-1.98 & -2.44 & -2.07 \\
\hline$[0.035]^{* *}$ & {$[0.031]^{* *}$} & {$[0.042]^{* *}$} \\
\hline 2.50 & 1.86 & 1.65 \\
\hline$[0.021]^{* *}$ & {$[0.030]^{* *}$} & {$[0.037]^{* *}$} \\
\hline-1.27 & -1.16 & -0.93 \\
\hline [0.252] & [0.219] & [0.294] \\
\hline 2.09 & 2.11 & 1.50 \\
\hline$[0.051]^{*}$ & {$[0.071]^{*}$} & {$[0.091] *$} \\
\hline 1.34 & 1.60 & 1.29 \\
\hline [0.155] & [0.193] & [0.240] \\
\hline 2.83 & 2.48 & 2.03 \\
\hline$[0.030]^{* *}$ & {$[0.032]^{* *}$} & {$[0.040]^{* *}$} \\
\hline 4.05 & 5.40 & 4.30 \\
\hline$[0.005] * * *$ & {$[0.007] * * *$} & {$[0.008]^{* * *}$} \\
\hline-1.64 & -1.38 & -1.74 \\
\hline [0.184] & [0.263] & [0.258] \\
\hline & 0.37 & 0.29 \\
\hline & [0.162] & [0.221] \\
\hline & 0.52 & 0.42 \\
\hline & {$[0.011]^{* *}$} & {$[0.013]^{* *}$} \\
\hline & -1.22 & -1.41 \\
\hline & {$[0.027]^{* *}$} & {$[0.037]^{* *}$} \\
\hline & 1.67 & 1.16 \\
\hline & {$[0.029]^{* *}$} & {$[0.035]^{* *}$} \\
\hline & \multicolumn{2}{|c|}{ 1996-2005 } \\
\hline yes & yes & yes \\
\hline yes & yes & yes \\
\hline yes & yes & yes \\
\hline 12,936 & 7,923 & 7,923 \\
\hline 26 & 23 & 23 \\
\hline 102 & 70 & 70 \\
\hline 0.19 & 0.19 & - \\
\hline
\end{tabular}

Sample period

Source country fixed effect

Recipient country fixed effect

Time fixed effect

Observations

No. of source countries

No. of recipient countries

$\begin{array}{lllll} & & & \\ & & & \\ & & & \\ & & & \\ & & & \\ & & & \\ -2.34 & -2.52 & -2.55 & -3.22 \\ {[0.035]^{* *}} & {[0.068]^{*}} & {[0.063]^{*}} & {[0.024]^{* *}} \\ 1.68 & 1.91 & 1.96 & 1.95 \\ {[0.031]^{* *}} & {[0.103]} & {[0.040]^{* *}} & {[0.108]} \\ -1.54 & -1.09 & -1.07 & -1.72 \\ {[0.017]^{* *}} & {[0.216]} & {[0.170]} & {[0.045]^{* *}} \\ 2.63 & 1.88 & 1.82 & 1.82 \\ {[0.050]^{*}} & {[0.027]^{* *}} & {[0.030]^{* *}} & {[0.031]^{* *}} \\ 3.75 & 2.80 & 2.20 & 2.48 \\ {[0.039]^{* *}} & {[0.064]^{*}} & {[0.269]} & {[0.041]^{* *}} \\ 2.01 & 1.67 & 1.79 & 1.42 \\ {[0.481]} & {[0.104]} & {[0.220]} & {[0.318]} \\ 2.51 & 3.94 & 3.99 & 4.05 \\ {[0.061]^{*}} & {[0.068]^{*}} & {[0.079]^{*}} & {[0.179]} \\ -1.56 & -1.48 & -1.85 & -1.71 \\ {[0.072]^{*}} & {[0.122]} & {[0.017]^{* *}} & {[0.111]}\end{array}$

$[0.072]^{*}$

[0.122]
[0.114]

2.22

[0.067]*

$-0.98$

[0.261]

1.21

[0.079]*

2.16

[0.108]

1.35

[0.170]

4.06

$[0.039]^{* *}$

$-1.66$

$[0.012]^{* *}$

\begin{tabular}{llllllll} 
yes & yes & yes & yes & yes & yes & yes & yes \\
yes & yes & yes & yes & yes & yes & yes & yes \\
yes & yes & yes & yes & yes & yes & yes & yes \\
14,430 & 13,738 & 13,790 & 13,467 & 13,601 & 12,936 & 7,923 & 7,923 \\
26 & 26 & 26 & 26 & 26 & 26 & 23 & 23 \\
120 & 111 & 111 & 108 & 109 & 102 & 70 & 70 \\
0.17 & 0.18 & 0.16 & 0.17 & 0.18 & 0.19 & 0.19 & - \\
\hline
\end{tabular}

Adj. R-squared

Note: The dependent variable is bank flows, which is defined as 100 times the log-difference of total foreign claims (FCsr) from source country $s$ to recipient country $r$, that is, $100^{*} \Delta \ln (F C s r)$. P-values are presented in brackets. The estimations are based on fixed effect OLS regressions for columns 1 to 7 and GMM for column 8 . P-values for columns 1 to 7 are computed by the heteroskedasticity-robust standard errors clustered for recipient countries. The GMM estimator and its corresponding p-values of coefficients are based on weighting matrix II of Bekaert et al. (2001, p.477), which is an extended panel-data version of Newey and West (1987) robust covariance matrix that facilitates serial correlation, cross-country heteroskedasticity, and restricted SUR effects (i.e., the off-diagonal elements of the variance-covariance matrices are restricted to be identical). The lag length of the GMM estimator is chosen as 3 due to our limited 10-year sample period (Greene, 2008, p.643). The country level banking regulatory variables are time varying and are based on three major surveys spanning almost over a decade by the World Bank (Barth, Caprio, and Levine, 2008). The values of regulatory variables for the period of 1996 to 1999 are taken from the first survey recorded in 1998/1999. Their values for the period of 2000 to 2003 are taken from the second survey that assesses the state of regulation as of the end of 2002 . Their values for the period of 2004 to 2007 are taken from the third survey that was sought a characterization of the environment as of the end of 2005. Detailed variable definitions can be found in Table 1. Time fixed effects, as well as source and recipient country specific effects are included in the regressions but not reported. *, **, $* * *$ represent statistical significance at the $10 \%, 5 \%$ and $1 \%$ level respectively. 
Table 5 Instrumental Variable Analyses

\begin{tabular}{|c|c|c|c|c|c|c|}
\hline & 1 & 2 & 3 & 4 & 5 & 6 \\
\hline \multirow[t]{2}{*}{ Overall activities restrictions (source) } & 0.86 & & & & 0.60 & 0.53 \\
\hline & {$[0.003]^{* * *}$} & & & & {$[0.000]^{* * *}$} & {$[0.000]^{* * *}$} \\
\hline \multirow[t]{2}{*}{ Overall activities restrictions (recipient) } & -0.43 & & & & -0.57 & -0.46 \\
\hline & {$[0.013]^{* *}$} & & & & {$[0.016]^{* *}$} & {$[0.015]^{* *}$} \\
\hline \multirow[t]{2}{*}{ Restriction on banks own nonfin firms (source) } & 2.55 & & & & 2.50 & 2.73 \\
\hline & {$[0.069]^{*}$} & & & & {$[0.020]^{* *}$} & {$[0.015]^{* *}$} \\
\hline \multicolumn{7}{|l|}{ Restriction on banks own nonfin firms } \\
\hline \multirow[t]{2}{*}{ (recipient) } & -2.82 & & & & -2.66 & -2.08 \\
\hline & {$[0.012]^{* *}$} & & & & {$[0.126]$} & {$[0.114]$} \\
\hline \multirow[t]{2}{*}{ capital regulatory index (source) } & & 0.87 & & & 0.43 & 0.46 \\
\hline & & {$[0.027]^{* *}$} & & & {$[0.092]^{*}$} & {$[0.077]^{*}$} \\
\hline \multirow[t]{2}{*}{ capital regulatory index (recipient) } & & -0.83 & & & -0.73 & -0.98 \\
\hline & & [0.059]* & & & {$[0.034]^{* *}$} & {$[0.018]^{* *}$} \\
\hline \multirow[t]{2}{*}{ strength of external audit (source) } & & & 1.40 & & 0.73 & 1.18 \\
\hline & & & {$[0.024]^{* *}$} & & [0.484] & [0.241] \\
\hline \multirow[t]{2}{*}{ strength of external audit (recipient) } & & & -0.57 & & -0.94 & -1.20 \\
\hline & & & {$[0.062]^{*}$} & & {$[0.020]^{* *}$} & {$[0.009]^{* * *}$} \\
\hline \multirow[t]{2}{*}{ fin statement transparency (source) } & & & 3.09 & & 2.60 & 3.66 \\
\hline & & & {$[0.031]^{* *}$} & & {$[0.004]^{* * *}$} & {$[0.012]^{*}$} \\
\hline \multirow[t]{2}{*}{ fin statement transparency (recipient) } & & & -1.66 & & -1.09 & -1.17 \\
\hline & & & {$[0.028]^{* *}$} & & {$[0.021]^{* *}$} & [0.059]* \\
\hline \multirow[t]{2}{*}{ Independence of Supervisory Authority (source) } & & & & 1.66 & 2.23 & 1.48 \\
\hline & & & & {$[0.053]^{*}$} & {$[0.047]^{* *}$} & [0.302] \\
\hline \multirow{3}{*}{$\begin{array}{l}\text { Independence of Supervisory Authority } \\
\text { (recipient) }\end{array}$} & & & & & & \\
\hline & & & & -1.16 & -0.87 & -1.33 \\
\hline & & & & {$[0.041]^{* *}$} & {$[0.041]^{* *}$} & {$[0.025]^{* *}$} \\
\hline \multirow[t]{2}{*}{ Official Supervisory Power (source) } & & & & 0.87 & 1.31 & 0.95 \\
\hline & & & & {$[0.038]^{* *}$} & {$[0.032]^{* *}$} & {$[0.036]^{* *}$} \\
\hline \multirow[t]{2}{*}{ Official Supervisory Power (recipient) } & & & & -0.67 & -0.94 & -1.06 \\
\hline & & & & {$[0.060]^{*}$} & {$[0.029]^{* *}$} & {$[0.023]^{* *}$} \\
\hline \multirow[t]{2}{*}{ Loan classification leniency (source) } & & & & & -0.45 & -0.38 \\
\hline & & & & & {$[0.000]^{* * *}$} & {$[0.015]^{* *}$} \\
\hline \multirow[t]{2}{*}{ Loan classification leniency (recipient) } & & & & & 0.66 & 0.56 \\
\hline & & & & & {$[0.014]^{* *}$} & {$[0.027]^{* *}$} \\
\hline \multirow[t]{2}{*}{ Creditor rights (source) } & -4.86 & -3.58 & -2.81 & -3.16 & -2.44 & -3.62 \\
\hline & {$[0.007]^{* * *}$} & {$[0.016]^{* *}$} & {$[0.055]^{*}$} & {$[0.102]$} & {$[0.020]^{* *}$} & {$[0.014]^{* *}$} \\
\hline \multirow[t]{2}{*}{ Creditor rights (recipient) } & 4.56 & 3.86 & 4.16 & 4.54 & 3.22 & 3.61 \\
\hline & {$[0.020]^{* *}$} & [0.069]* & {$[0.034]^{* *}$} & {$[0.044]^{* *}$} & {$[0.014]^{* *}$} & {$[0.017]^{* *}$} \\
\hline \multirow[t]{2}{*}{ Info sharing (source) } & -0.70 & -0.39 & -0.74 & -0.67 & -0.47 & -0.06 \\
\hline & {$[0.015]^{* *}$} & {$[0.060]^{*}$} & {$[0.008]^{* * *}$} & {$[0.015]^{* *}$} & {$[0.045]^{* *}$} & {$[0.059]^{*}$} \\
\hline Info sharing (recipient) & 1.12 & 1.00 & 1.15 & 0.94 & 1.23 & 1.42 \\
\hline
\end{tabular}




\begin{tabular}{lllllll}
\hline & {$[0.021]^{* *}$} & {$[0.027]^{* *}$} & {$[0.018]^{* *}$} & {$[0.061]^{*}$} & {$[0.046]^{* *}$} & {$[0.045]^{* *}$} \\
Property rights (source) & -2.87 & -2.56 & -3.25 & -2.47 & -1.73 & -2.44 \\
& {$[0.054]^{*}$} & {$[0.061]^{*}$} & {$[0.022]^{* *}$} & {$[0.125]$} & {$[0.029]^{* *}$} & {$[0.039]^{* *}$} \\
Property rights (recipient) & 1.89 & 1.95 & 1.94 & 2.23 & 2.32 & 1.87 \\
& {$[0.105]$} & {$[0.039]^{* *}$} & {$[0.106]$} & {$[0.063]^{*}$} & {$[0.022]^{* *}$} & {$[0.031]^{* *}$} \\
\hline Sample period & & & $1996-2007$ & & & $1996-2005$ \\
Other control variables & yes & yes & yes & yes & yes & yes \\
Source country fixed effect & yes & yes & yes & yes & yes & yes \\
Recipient country fixed effect & yes & yes & yes & yes & yes & yes \\
Time fixed effect & yes & yes & yes & yes & yes & yes \\
1st-stage F-test (p-value) & 0.000 & 0.000 & 0.000 & 0.000 & 0.000 & 0.000 \\
Sargan's over-identification test (p-value) & 0.24 & 0.23 & 0.16 & 0.21 & 0.33 & 0.19 \\
Observations & 13,738 & 13,790 & 13,467 & 13,601 & 12,936 & 7,923 \\
No. of recipient countries & 26 & 26 & 26 & 26 & 26 & 23 \\
No. of source countries & 111 & 111 & 108 & 109 & 102 & 70 \\
Adj. R-squared & 0.26 & 0.25 & 0.23 & 0.24 & 0.26 & 0.27 \\
\hline
\end{tabular}

Note: The dependent variable is bank flows, which is defined as 100 times the log-difference of the ratio of total foreign claims (FCsr) from source country $s$ to recipient country $r$, that is, $100 * \Delta \ln (F C s r)$. The estimation is based on IV regressions. 1st-stage F-test is the test of excluded instrument in the first-stage regression. For Sargan's over-identification test, the null hypothesis is that the instruments used are not correlated with the residuals. Instrumental variables include the experience of banking supervisors, a dummy for central bank as supervisor, Gini coefficients as a measure of income inequality (past 5-year moving average), percentage of years since 1776 that a country has been independent, ethnic fractionalization, latitude, the average regulatory level of other countries in the sample in a specific year. Other control variables include log income (source and recipient), $\log$ population (source and recipient), common language and log distance. In column 6 , other control variables also include financial liberalization (source and recipient) and growth opportunity (source and recipient). Time fixed effects, as well as source and recipient country specific effects are included in the regressions but not reported. Detailed variable definitions can be found in Table 1. P-values are computed by the heteroskedasticity-robust standard errors clustered for recipient countries and are presented in brackets. *, **, *** represent statistical significance at the $10 \%, 5 \%$ and $1 \%$ level respectively. 
Table 6. Split sample estimation: Regulation arbitrage activities over time and across quality of institutions

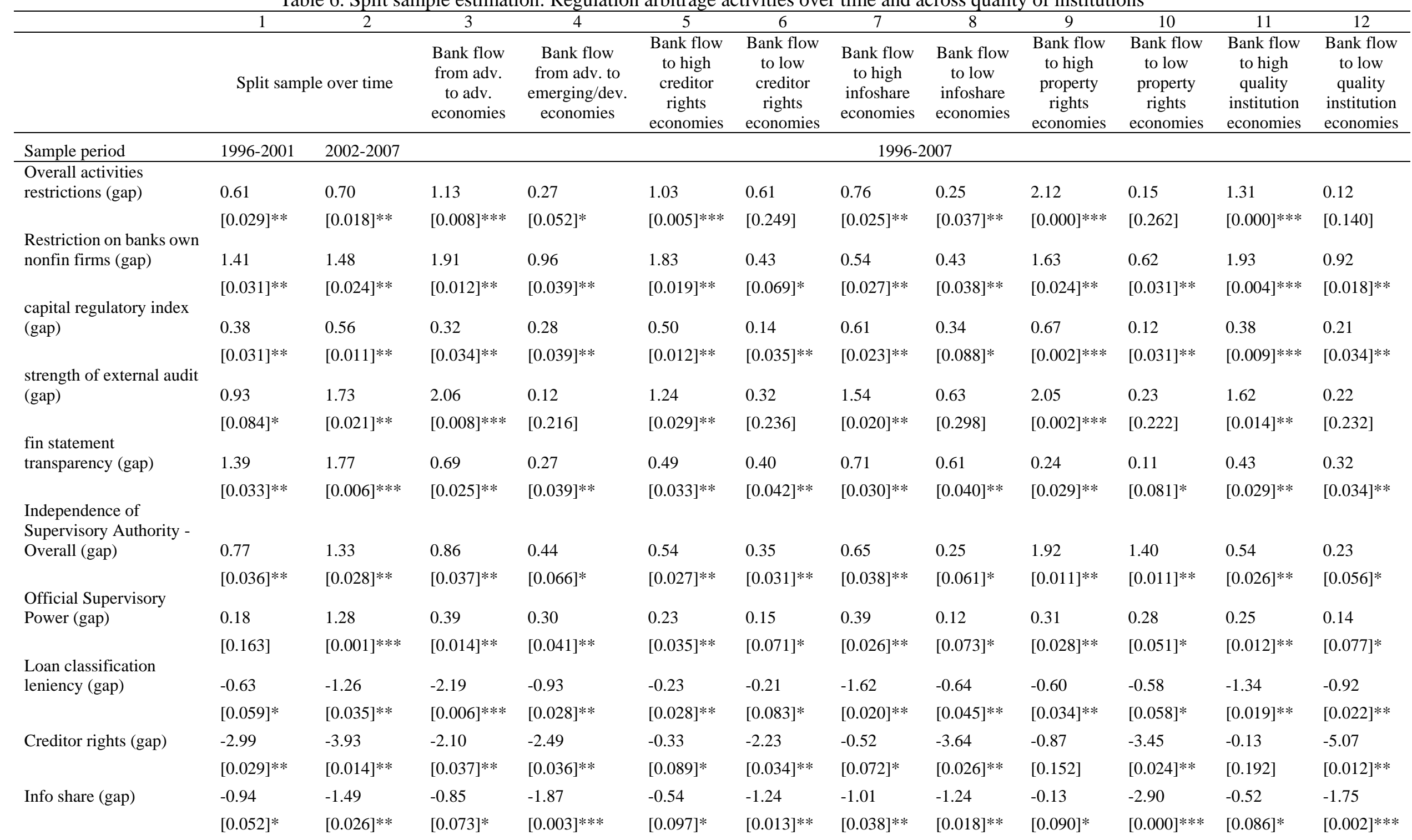




\begin{tabular}{|c|c|c|c|c|c|c|c|c|c|c|c|c|}
\hline Property rights (gap) & $\begin{array}{l}-2.26 \\
{[0.017]^{* *}}\end{array}$ & $\begin{array}{l}-2.46 \\
{[0.176]} \\
\end{array}$ & $\begin{array}{l}-1.91 \\
{[0.012]^{* *}}\end{array}$ & $\begin{array}{l}-2.25 \\
{[0.007]^{* * *}}\end{array}$ & $\begin{array}{l}-0.39 \\
{[0.075]^{*}}\end{array}$ & $\begin{array}{l}-0.86 \\
{[0.052]^{*}}\end{array}$ & $\begin{array}{l}-0.67 \\
{[0.128]} \\
\end{array}$ & $\begin{array}{l}-1.29 \\
{[0.040]^{* *}}\end{array}$ & $\begin{array}{l}-2.01 \\
{[0.014]^{* *}}\end{array}$ & $\begin{array}{l}-2.87 \\
{[0.000]^{* * *}}\end{array}$ & $\begin{array}{l}-1.44 \\
{[0.027]^{* *}}\end{array}$ & $\begin{array}{l}-1.62 \\
{[0.004]^{* * *}}\end{array}$ \\
\hline \multirow{3}{*}{$\begin{array}{l}\text { Other Controls } \\
\text { Source country fixed } \\
\text { effect } \\
\text { Recipient country fixed } \\
\text { effect }\end{array}$} & yes & yes & yes & yes & yes & yes & yes & yes & yes & yes & yes & yes \\
\hline & yes & yes & yes & yes & yes & yes & yes & yes & yes & yes & yes & yes \\
\hline & yes & yes & yes & yes & yes & yes & yes & yes & yes & yes & yes & yes \\
\hline Time fixed effect & yes & yes & yes & yes & yes & yes & yes & yes & yes & yes & yes & yes \\
\hline Observations & 5,446 & 7,640 & 4,150 & 8,398 & 7,837 & 5,249 & 6,652 & 6,434 & 6,675 & 6,411 & 6,828 & 6,258 \\
\hline No. of source countries & 19 & 26 & 21 & 19 & 26 & 26 & 26 & 24 & 26 & 24 & 26 & 25 \\
\hline No. of recipient countries & 103 & 103 & 29 & 74 & 63 & 47 & 45 & 58 & 45 & 58 & 47 & 58 \\
\hline Adj. R-squared & 0.14 & 0.15 & 0.14 & 0.16 & 0.15 & 0.14 & 0.13 & 0.14 & 0.13 & 0.14 & 0.13 & 0.14 \\
\hline
\end{tabular}

Note: The dependent variable is bank flows, which is defined as 100 times the log-difference of the total foreign claims (FCsr) from source country $s$ to recipient country $r$, that is, $100 * \Delta \ln (F C s r)$. The estimation is based on fixed effect OLS regressions. The country level banking regulatory variables are time varying and are based on three major surveys spanning almost over a decade by the World Bank (Barth, Caprio, and Levine, 2008). The values of regulatory variables for the period of 1996 to 1999 are taken from the first survey recorded in 1998/1999. Their values for the period of 2000 to 2003 are taken from the second survey that assesses the state of regulation as of the end of 2002. Their values for the period of 2004 to 2007 are taken from the third survey that was sought a characterization of the environment as of the end of 2005. Detailed variable definitions can be found in Table 1. Other control variables include log income (gap), log population (gap), common language, log distance. Time fixed effects, as well as source and recipient country specific effects are included in the regressions but not reported. P-values are computed by the heteroskedasticity-robust standard errors clustered for recipient countries and are presented in brackets. *, **, *** represent statistical significance at the $10 \%, 5 \%$ and $1 \%$ level respectively. To define the high/low quality institution recipient countries in terms of the three indicators of creditor rights, depth of information sharing (infoshare), and property rights, we first calculate the average institution quality of each indicator for each country over time. If the average institution quality of an indicator for a country is equal or above the sample medium level, the country is defined as a high quality institution country for this particular indicator. The remaining countries are defined as low quality institution countries for this indicator. Next we combine the above three individual institution quality indicators to obtain an aggregate measure of the overall institution quality for each country. For each individual indicator, we assign a value of one to a high quality country and zero to a low quality country. Then we sum the scores of each country across the three indicators to obtain the overall measure of institution quality of a country. The value of this aggregate measure goes from zero (lowest institution quality country) to three (highest institution quality country). If the aggregate measure of a country is equal or above the sample medium level, the country is defined as an overall high quality institution country. The remaining countries are defined as low quality institution countries. 
Table 7. Probit estimation: Bank’s foreign affiliates and regulatory arbitrage

\begin{tabular}{|c|c|c|c|c|c|c|c|}
\hline & 1 & 2 & 3 & 4 & 5 & 6 & 7 \\
\hline \multirow[t]{2}{*}{ Overall activities restrictions (source) } & 0.029 & & & & 0.028 & 0.030 & 0.043 \\
\hline & {$[0.067]^{*}$} & & & & {$[0.031]^{* *}$} & ${ }^{k}[0.012]^{* *}$ & {$[0.023]^{* *}$} \\
\hline \multirow[t]{2}{*}{ Overall activities restrictions (recipient) } & -0.018 & & & & -0.012 & -0.014 & -0.042 \\
\hline & {$[0.027]^{* *}$} & & & & {$[0.019]^{* *}$} & ${ }^{k}[0.023]^{* *}$ & {$[0.014]^{* *}$} \\
\hline \multirow[t]{2}{*}{$\begin{array}{l}\text { Restriction on banks own nonfin firms } \\
\text { (source) }\end{array}$} & 0.063 & & & & 0.064 & 0.065 & 0.069 \\
\hline & {$[0.024]^{*=}$} & & & & {$[0.037]^{* *}$} & {$[0.074]^{*}$} & {$[0.031]^{* *}$} \\
\hline \multirow[t]{2}{*}{$\begin{array}{l}\text { Restriction on banks own nonfin firms } \\
\text { (recipient) }\end{array}$} & -0.049 & & & & -0.041 & -0.036 & -0.049 \\
\hline & {$[0.029]^{* *}$} & & & & {$[0.020]^{* *}$} & ${ }^{k}[0.017]^{* *}$ & {$[0.028]^{* *}$} \\
\hline \multirow[t]{2}{*}{ Capital regulatory index (source) } & & 0.027 & & & 0.027 & 0.021 & 0.049 \\
\hline & & {$[0.018]^{* *}$} & & & {$[0.015]^{* *}$} & ${ }^{k}[0.021]^{* *}$ & {$[0.026]^{* *}$} \\
\hline \multirow[t]{2}{*}{ Capital regulatory index (recipient) } & & -0.011 & & & -0.012 & -0.014 & -0.027 \\
\hline & & {$[0.014]^{* *}$} & & & {$[0.016]^{* *}$} & {$[0.029]^{* *}$} & {$[0.012]^{* *}$} \\
\hline \multirow[t]{2}{*}{ Strength of external audit (source) } & & & 0.040 & & 0.044 & 0.053 & 0.056 \\
\hline & & & {$[0.032]^{* *}$} & & {$[0.038]^{* *}$} & * $[0.079] *$ & {$[0.013]^{* *}$} \\
\hline \multirow[t]{2}{*}{ Strength of external audit (recipient) } & & & -0.032 & & -0.031 & -0.047 & -0.048 \\
\hline & & & {$[0.128]$} & & {$[0.025]^{* *}$} & ${ }^{*}[0.031]^{* *}$ & {$[0.026]^{* *}$} \\
\hline \multirow[t]{2}{*}{ Fin statement transparency (source) } & & & 0.035 & & 0.033 & 0.030 & 0.020 \\
\hline & & & {$[0.011]^{* *}$} & & {$[0.030]^{* *}$} & ${ }^{*}[0.029]^{* *}$ & {$[0.015]^{* *}$} \\
\hline \multirow[t]{2}{*}{ Fin statement transparency (recipient) } & & & -0.018 & & -0.024 & -0.016 & -0.032 \\
\hline & & & {$[0.019]^{* *}$} & & {$[0.024]^{* *}$} & ${ }^{k}[0.019]^{* *}$ & {$[0.028]^{* *}$} \\
\hline \multirow[t]{2}{*}{$\begin{array}{l}\text { Independence of supervisory authority } \\
\text { (source) }\end{array}$} & & & & 0.057 & 0.046 & 0.051 & 0.049 \\
\hline & & & & {$[0.017]^{* *}$} & {$[0.012]^{* *}$} & ${ }^{*}[0.033]^{* *}$ & {$[0.009]^{* * *}$} \\
\hline \multirow[t]{2}{*}{$\begin{array}{l}\text { Independence of supervisory authority } \\
\text { (recipient) }\end{array}$} & & & & -0.023 & -0.025 & -0.027 & -0.029 \\
\hline & & & & {$[0.015]^{* *}$} & {$[0.031]^{* *}$} & {$[0.029]^{* *}$} & {$[0.023]^{* *}$} \\
\hline \multirow[t]{2}{*}{ Official supervisory power (source) } & & & & 0.036 & 0.037 & 0.038 & 0.039 \\
\hline & & & & {$[0.011]^{* *}$} & {$[0.019]^{* *}$} & ${ }^{k}[0.053]^{*}$ & {$[0.011]^{* *}$} \\
\hline \multirow[t]{2}{*}{ Official supervisory power (recipient) } & & & & -0.028 & -0.025 & -0.020 & -0.049 \\
\hline & & & & {$[0.051]^{*}$} & {$[0.016]^{* *}$} & ${ }^{*}[0.014]^{* *}$ & {$[0.031]^{* *}$} \\
\hline \multirow[t]{2}{*}{ Loan classification leniency (source) } & & & & & -0.044 & -0.041 & -0.057 \\
\hline & & & & & {$[0.060]^{*}$} & {$[0.035]^{* *}$} & {$[0.038]^{* *}$} \\
\hline \multirow[t]{2}{*}{ Loan classification leniency (recipient) } & & & & & 0.025 & 0.024 & 0.021 \\
\hline & & & & & {$[0.030]^{* *}$} & ${ }^{k}[0.058]^{*}$ & {$[0.013]^{* *}$} \\
\hline \multirow[t]{2}{*}{ Government bank ownership (recipient) } & & & & & -0.361 & -0.376 & -0.355 \\
\hline & & & & & {$[0.037]^{* *}$} & ${ }^{*}[0.034]^{* *}$ & {$[0.034]^{* *}$} \\
\hline \multirow[t]{2}{*}{$\begin{array}{l}\text { Top } 5 \text { bank concentration (all banks) } \\
\text { (recipient) }\end{array}$} & & & & & -0.208 & & -0.234 \\
\hline & & & & & {$[0.016]^{* *}$} & & {$[0.035]^{* *}$} \\
\hline \multirow[t]{2}{*}{$\begin{array}{l}\text { Top } 5 \text { bank concentration (excl. foreign } \\
\text { banks) (recipient) }\end{array}$} & & & & & & -0.287 & \\
\hline & & & & & & {$[0.016]^{* *}$} & \\
\hline Bank size & 0.016 & 0.015 & 0.014 & 0.016 & 0.017 & 0.018 & 0.016 \\
\hline
\end{tabular}




\begin{tabular}{|c|c|c|c|c|c|c|c|}
\hline \multirow{3}{*}{ Bank net income } & {$[0.130]$} & {$[0.178]$} & {$[0.118]$} & {$[0.133]$} & \multicolumn{2}{|c|}{$[0.042]^{* *}[0.168]$} & \multirow{2}{*}{$\begin{array}{l}{[0.041]^{* *}} \\
0.057\end{array}$} \\
\hline & 0.036 & 0.031 & 0.030 & 0.023 & 0.039 & 0.038 & \\
\hline & {$[0.033]^{* *}$} & {$[0.089]^{*}$} & {$[0.060]^{*}$} & {$[0.113]$} & {$[0.171]$} & {$[0.047]^{* *}$} & {$[0.186]$} \\
\hline \multirow[t]{2}{*}{ Creditor rights (source) } & -0.039 & -0.034 & -0.035 & -0.032 & -0.029 & -0.038 & -0.039 \\
\hline & {$[0.090]^{*}$} & {$[0.058]^{*}$} & {$[0.069]^{*}$} & {$[0.022]^{* *}$} & {$[0.026]^{* *}$} & {$[0.036]^{* *}$} & {$[0.029]^{* *}$} \\
\hline \multirow[t]{2}{*}{ Creditor rights (recipient) } & 0.024 & 0.026 & 0.024 & 0.026 & 0.018 & 0.023 & 0.025 \\
\hline & {$[0.083]^{*}$} & {$[0.060]^{*}$} & {$[0.057]^{*}$} & {$[0.046]^{* *}$} & {$[0.095]^{*}$} & {$[0.063]^{*}$} & {$[0.069]^{*}$} \\
\hline \multirow[t]{2}{*}{ Info sharing (source) } & -0.031 & -0.032 & -0.032 & -0.031 & -0.034 & -0.038 & -0.030 \\
\hline & {$[0.044]^{* *}$} & {$[0.024]^{* *}$} & {$[0.036]^{* *}$} & {$[0.078]^{*}$} & {$[0.021]^{* *}$} & {$[0.069]^{*}$} & {$[0.020]^{* *}$} \\
\hline \multirow[t]{2}{*}{ Info sharing (recipient) } & 0.015 & 0.016 & 0.021 & 0.014 & 0.019 & 0.024 & 0.032 \\
\hline & {$[0.087]^{*}$} & {$[0.008]^{* * *}$} & {$[0.006]^{* * *}$} & {$[0.086]^{*}$} & {$[0.069]^{*}$} & {$[0.037]^{* *}$} & {$[0.011]^{* *}$} \\
\hline \multirow[t]{2}{*}{ Property rights (source) } & -0.024 & -0.025 & -0.020 & -0.028 & -0.037 & -0.037 & -0.027 \\
\hline & {$[0.053]^{*}$} & {$[0.043]^{* *}$} & {$[0.008]^{* * *}$} & {$[0.051]^{*}$} & {$[0.084]^{*}$} & {$[0.003]^{* * *}$} & {$[0.078]^{*}$} \\
\hline \multirow[t]{2}{*}{ Property rights (recipient) } & 0.019 & 0.022 & 0.015 & 0.024 & 0.029 & 0.021 & 0.026 \\
\hline & {$[0.062]^{*}$} & {$[0.036]^{* *}$} & {$[0.029]^{* *}$} & {$[0.093]^{*}$} & {$[0.043]^{* *}$} & {$[0.068]^{*}$} & {$[0.019]^{* *}$} \\
\hline \multirow[t]{2}{*}{ Fin liberalization (source) } & & & & & & & 0.039 \\
\hline & & & & & & & {$[0.319]$} \\
\hline \multirow[t]{2}{*}{ Fin liberalization (recipient) } & & & & & & & 0.044 \\
\hline & & & & & & & {$[0.028]^{* *}$} \\
\hline \multirow{2}{*}{ Growth opportunity (source) } & & & & & & & -0.317 \\
\hline & & & & & & & {$[0.016]^{* *}$} \\
\hline \multirow[t]{2}{*}{ Growth opportunity (recipient) } & & & & & & & 0.712 \\
\hline & & & & & & & {$[0.018]^{* *}$} \\
\hline Source countries & 26 & 26 & 26 & 26 & 26 & 26 & 24 \\
\hline Recipient countries & 111 & 111 & 108 & 109 & 103 & 103 & 70 \\
\hline Banks & 301 & 301 & 301 & 301 & 301 & 301 & 284 \\
\hline Other control variables & yes & yes & yes & yes & yes & yes & yes \\
\hline Observations & 33,110 & 33,110 & 32,207 & 32,508 & 30,702 & 30,702 & 19,596 \\
\hline
\end{tabular}

Note: The dependent variable for columns (1) to (5) and (7) is a dummy that takes the value of one if the bank headquartered in source country $s$ has a foreign subsidiary in recipient country $r$, and is zero otherwise, in 2008. The dependent variable for column (6) is a dummy that takes the value of one if the bank headquartered in source country $s$ has either a foreign subsidiary or a foreign branch in recipient country $r$, and is zero otherwise, in 2008. The estimation is via probit model. The explanatory variables are for year 2007. Bank size and net income are the 3-year average values over 2005-2007. The coefficient estimates are transformed to represent the marginal effects evaluated at the means of the independent variables from the interval regressions. The marginal effect of a dummy variable is calculated as the discrete change in the expected value of the dependent variable as the dummy variable changes from 0 to 1 . Other control variables include log income (source and recipient), $\log$ population (source and recipient), common language and log distance. P-values are computed by the heteroskedasticity-robust standard errors clustered for recipient countries and are presented in brackets. *, **, *** represent statistical significance at the $10 \%, 5 \%$ and $1 \%$ level respectively. 
Figure 1. Changes of regulation and changes of credit inflows in recipient countries
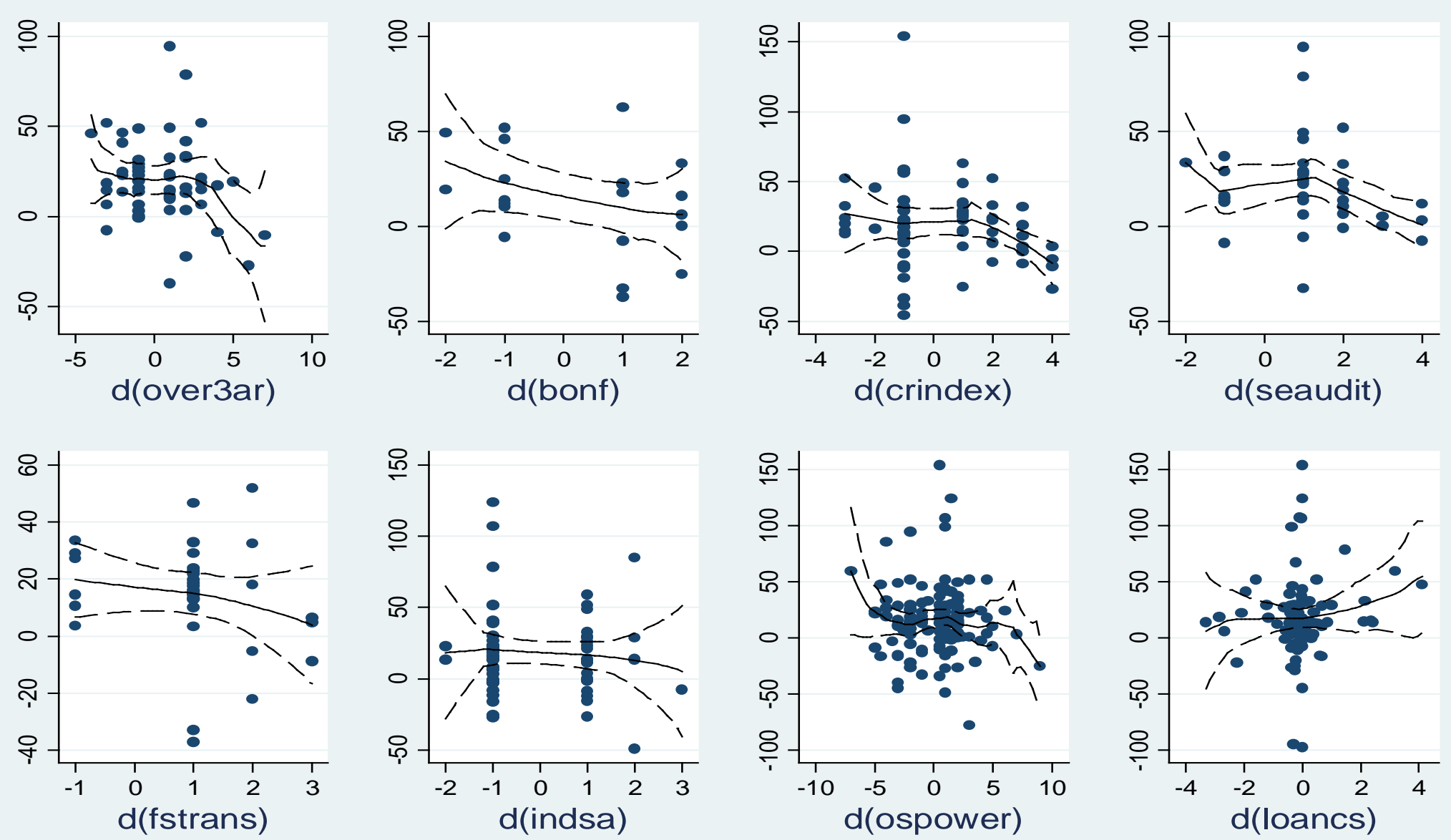

Note: This figure presents the non-parametric (kernel-weighted local polynomial smoothing) plot of the changes in regulation of recipient countries on the X-axis, and changes in credit inflows on the Y-axis. The solid line is the fitted credit inflows with 95\% confidence region (Fan and Gijbels, 1996) in dashed lines. Over3ar is overall activities restrictions for the banking sector, bonf is restriction on banks own non-financial firms, crindex is capital regulatory index, seaudit is strength of external audit, fstrans is financial statement transparency, indsa is independence of supervisory authority, ospower is official supervisory power, and loancs is loan classification leniency. Among 120 recipient countries in our sample, we find that 114 recipient countries/regions have changed at least one type of regulations during the past decade. 
Fig 2. Changes of regulation and changes of credit outflows from source countries
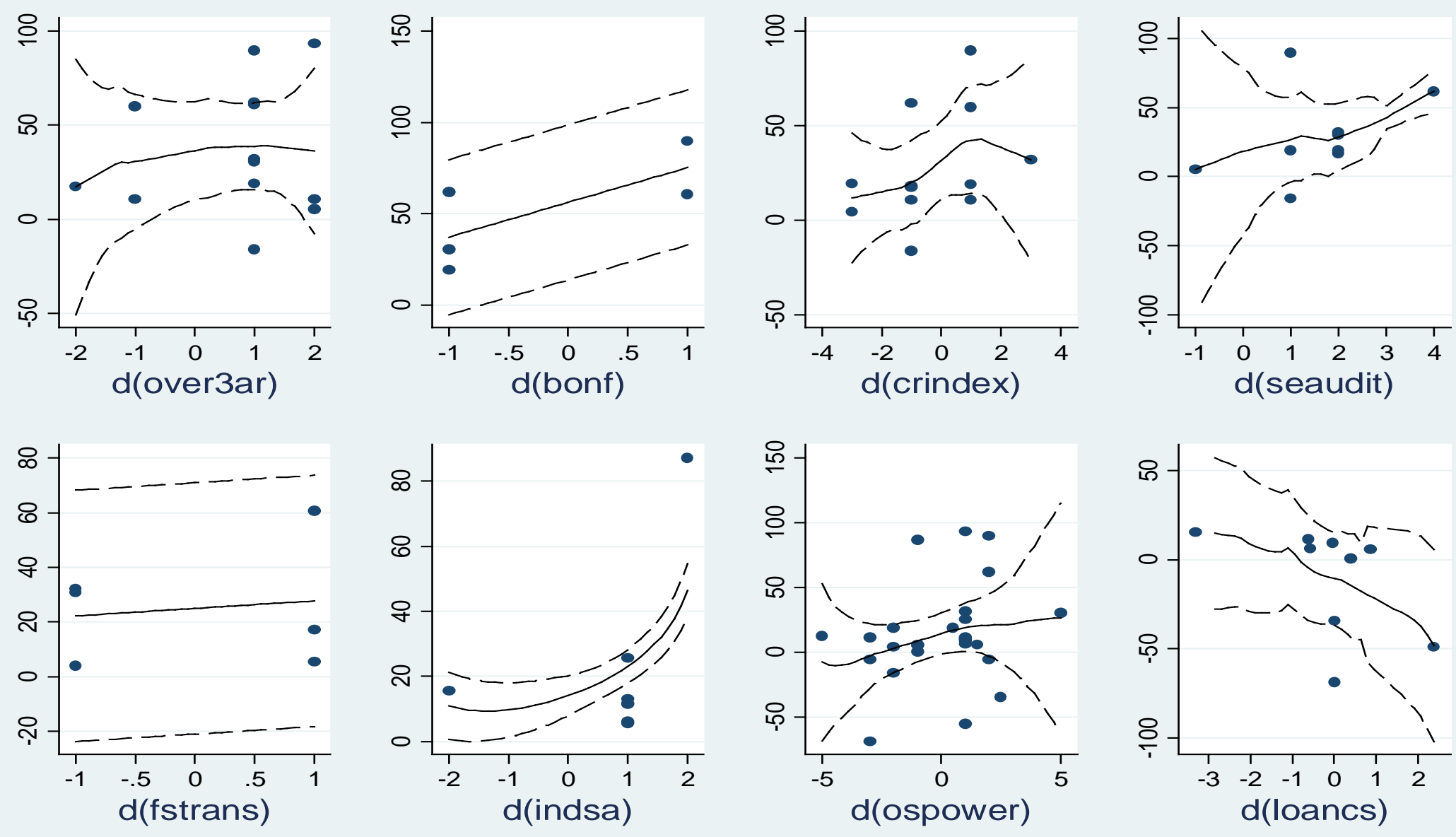

Note: This figure presents the non-parametric (kernel-weighted local polynomial smoothing) plot of the changes in regulation of source countries on the X-axis, and changes in credit outflows on the Y-axis. The solid line is the fitted credit outflows with 95\% confidence region (Fan and Gijbels, 1996) in dashed lines. Over3ar is overall activities restrictions for the banking sector, bonf is restriction on banks own non-financial firms, crindex is capital regulatory index, seaudit is strength of external audit, fstrans is financial statement transparency, indsa is independence of supervisory authority, ospower is official supervisory power, and loancs is loan classification leniency. Among 26 source countries in our sample, we find that 21 countries/regions have changed at least one type of regulations during the past decade. 


\title{
Internet Appendix for "Regulatory Arbitrage and International Bank Flows” *
}

\author{
Joel F. Houston, Chen Lin, Yue Ma
}

*Citation format: Joel F. Houston, Chen Lin and Yue Ma, 2011, Internet Appendix to "Regulatory Arbitrage and International Bank Flows," Journal of Finance \{vol \#], pages [ ], http://www.afajof.org/IA/[year].asp. Please note: Wiley-Blackwell is not responsible for the content or functionality of any supporting information supplied by the authors. Any queries (other than missing material) should be directed to the authors of the article. 


\section{Data Appendix}

Our main dependent variable used in this paper is the international bilateral bank flow from 26 primarily OECD source countries ${ }^{22}$ to 120 recipient countries ${ }^{23}$. The bilateral bank flow consists of bank loans and portfolio investments aggregated from banks located in a source country to all sectors of the economy in a recipient country. It is a panel dataset consists of bilateral country level data.

Our bank flow panel data is constructed from the banking sector bilateral stock data published in the International Banking Statistics by the Bank for International Settlements (BIS). The BIS Consolidated/Nationality Banking Statistics publish aggregate foreign financial claims reported by domestic bank head offices, including the exposures of their foreign affiliates (i.e. branches and subsidiaries), and are collected on a worldwide consolidated basis with inter-office positions being netted out (BIS, 2003, p.55). These claims consist of financial assets such as loans, debt securities, properties, and equities, including equity participations in subsidiaries (BIS, 2003). The data are published in Table 9B of the BIS Quarterly Review on a quarterly basis since December 1983 under the title "The consolidated foreign claims of reporting banks". The data are in a matrix form with different source country/recipient country combinations. The most recent cross sectional data can be downloaded from http://www.bis.org/statistics/pcsv/panx9b.csv and the full historical data can be downloaded from the BIS website: www.bis.org/statistics/hcsv/hanx9b.csv

This database provides comprehensive data on banks' financial claims extended on residents outside the country in which these banks are headquartered. It is important to stress that the bank's home country is determined by the reporting bank's nationality not its geographic location. So, for example, a loan issued by the US bank located in London to a British bank operating in London is

\footnotetext{
${ }^{22}$ The 26 source countries/regions are: Australia, Austria, Belgium, Brazil, Canada, Chile, Denmark, Finland, France, Germany, Greece, Ireland, Italy, Japan, Mexico, Netherlands, Norway, Panama, Portugal, Spain, Sweden, Switzerland, Taiwan, Turkey, United Kingdom, and United States.

${ }^{23}$ The 120 recipient countries/regions are: Albania, Algeria, Angola, Argentina, Armenia, Australia, Austria, Azerbaijan, Bangladesh, Belgium, Benin, Bolivia, Bosnia and Herzegovina, Botswana, Brazil, Bulgaria, Burkina Faso, Burundi, Cameroon, Canada, Central African Republic, Chad, Chile, China, Colombia, Dem. Rep. Congo, Rep. Congo, Costa Rica, Croatia, Czech Republic, Denmark, Dominican Republic, Ecuador, Egypt, El Salvador, Ethiopia, Finland, France, Georgia, Germany, Ghana, Greece, Guatemala, Haiti, Honduras, Hong Kong, Hungary, India, Indonesia, Iran, Ireland, Israel, Italy, Jamaica, Japan, Jordan, Kazakhstan, Kenya, Korea, Latvia, Lesotho, Lithuania, Macedonia, Madagascar, Malawi, Malaysia, Mali, Mauritania, Mexico, Moldova, Mongolia, Morocco, Mozambique, Namibia, Nepal, Netherlands, New Zealand, Nicaragua, Niger, Nigeria, Norway, Oman, Pakistan, Panama, Papua New Guinea, Paraguay, Peru, Philippines, Poland, Portugal, Romania, Russian Federation, Rwanda, Senegal, Sierra Leone, Singapore, Slovak Republic, Slovenia, South Africa, Spain, Sri Lanka, Sweden, Switzerland, Syria, Taiwan, Tanzania, Thailand, Togo, Tunisia, Turkey, Uganda, Ukraine, United Arab Emirates, United Kingdom, United States, Uruguay, Venezuela, Vietnam, Zambia, Zimbabwe.
} 
recorded in the database as a foreign loan, where the source country is the US and the recipient country is the UK. However, a loan issued by the same US bank located in London to another US bank located in New York is regarded as a domestic loan issued by the US bank and is therefore not recorded in this database (for details, see Wooldridge, 2002).

For instance, if there was a huge US flow to their branches located in the UK but a lot of that flow was eventually headed towards emerging economies, the BIS data can actually capture the fact that these are indeed US bank inflows, rather than the UK bank inflows, to emerging economies.

As there is no flow measure in the BIS data, we construct a bank flow measure by calculating the annual difference of log total foreign claims for each bilateral source-recipient combination. Specifically, our bank flow is defined as 100 times the log-difference of the ratio of total foreign claims (FCsr) from source country s to recipient country $r$, that is, $100^{*} \Delta \ln (F C s r)$. We construct the annual bank flow variable by using the stock data (FCsr) on December of each year in our sample period of 1996-2007 to match the annual frequency of the other explanatory variables. 
Figure 1: the change of overall activities restrictions across countries (1999 vs. 2006)

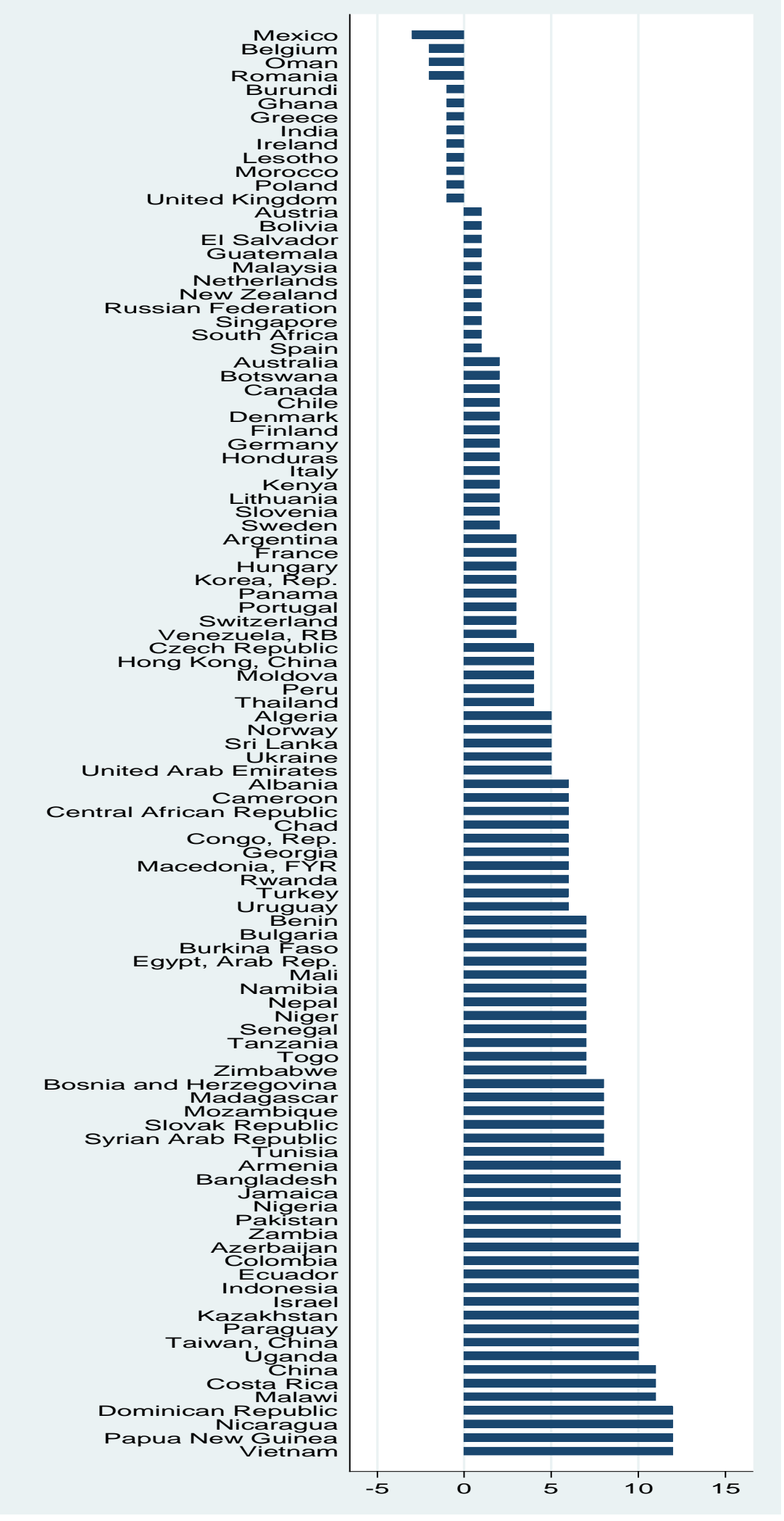

The regulation of the following countries has not been changed over 1999 to 2006: Brazil, Croatia, Japan, Jordan, Latvia,

Philippines, and United States. 
Internet Appendix Table 1: Correlation matrix of differenced variables

\begin{tabular}{|c|c|c|c|c|c|c|c|c|c|c|c|c|c|c|}
\hline & & 1 & 2 & 3 & 4 & 5 & 6 & 7 & 8 & 9 & 10 & 11 & 12 & 13 \\
\hline 1 & $\Delta$ Overall activities restrictions & 1 & & & & & & & & & & & & \\
\hline 2 & $\Delta$ Restriction on banks own nonfin firms & $0.11^{* *}$ & 1 & & & & & & & & & & & \\
\hline 3 & $\Delta$ capital regulatory index & 0.05 & 0.09 & 1 & & & & & & & & & & \\
\hline 4 & $\Delta$ strength of external audit & -0.09 & 0.01 & $0.21^{* * *}$ & 1 & & & & & & & & & \\
\hline 5 & $\Delta$ fin statement transparency & -0.06 & $0.11^{* *}$ & 0.09 & $0.23 * * *$ & 1 & & & & & & & & \\
\hline 6 & $\Delta$ Independence of supervisory authority & -0.01 & 0.00 & -0.09 & -0.07 & 0.09 & 1 & & & & & & & \\
\hline 7 & $\Delta$ Official Supervisory Power & 0.01 & $0.12^{* *}$ & 0.03 & $0.22 * * *$ & $0.20 * * *$ & 0 & 1 & & & & & & \\
\hline 8 & $\Delta$ Loan classification leniency & -0.11 & -0.08 & -0.01 & -0.03 & -0.01 & 0.08 & $-0.16^{* * *}$ & 1 & & & & & \\
\hline 9 & $\Delta$ Creditor rights & 0.01 & $-0.12^{*}$ & $0.14^{* *}$ & -0.02 & 0.06 & -0.02 & -0.01 & -0.1 & 1 & & & & \\
\hline 10 & $\Delta$ Info share & $-0.19 * *$ & -0.05 & -0.01 & $0.12^{* *}$ & $0.24 * * *$ & 0.02 & -0.01 & $0.25 * * *$ & -0.06 & 1 & & & \\
\hline 11 & $\Delta$ Property rights & $-0.20 * *$ & $-0.13^{* *}$ & -0.01 & 0.03 & -0.05 & 0.02 & 0.00 & $0.24 * * *$ & 0.00 & $0.26 * * *$ & 1 & & \\
\hline 12 & $\Delta \log$ income & -0.03 & -0.03 & 0.02 & 0.02 & 0.07 & 0.06 & 0.04 & 0.05 & -0.04 & 0.05 & 0.06 & 1 & \\
\hline 13 & $\Delta$ Log population & -0.01 & 0.04 & -0.03 & 0.01 & 0.06 & -0.07 & 0.01 & 0.04 & -0.05 & 0.04 & 0.00 & $0.12^{* *}$ & 1 \\
\hline
\end{tabular}

Note: This table examines the correlations among the changes of regulation and institution quality. The change of a variable is its difference between 2001 and 2004 and that between 2004 and 2007, that is, $\Delta x_{t}, t=2004$ and 2007. *, **, *** represent statistical significance at the $10 \%$, 5\% and $1 \%$ level respectively. 
Internet Appendix Table 2. Regulatory arbitrage and bank flows: various clustering effects

\begin{tabular}{|c|c|c|c|}
\hline & 1 & 2 & 3 \\
\hline Clustering by two dimensions & $\begin{array}{l}\text { By recipient } \\
\text { country and time }\end{array}$ & $\begin{array}{l}\text { By source country } \\
\text { and time }\end{array}$ & $\begin{array}{l}\text { By recipient-source } \\
\text { country pair and time }\end{array}$ \\
\hline \multirow[t]{2}{*}{ Overall activities restrictions (source) } & 0.36 & 0.36 & 0.36 \\
\hline & {$[0.009]^{* * *}$} & {$[0.017]^{* *}$} & {$[0.016]^{* *}$} \\
\hline \multirow[t]{2}{*}{ Overall activities restrictions (recipient) } & -0.33 & -0.33 & -0.33 \\
\hline & {$[0.018]^{* *}$} & {$[0.015]^{* *}$} & {$[0.029]^{* *}$} \\
\hline \multirow[t]{2}{*}{ Restriction on banks own nonfin firms (source) } & 1.52 & 1.52 & 1.52 \\
\hline & {$[0.029]^{* *}$} & {$[0.023]^{* *}$} & {$[0.028]^{* *}$} \\
\hline \multirow[t]{2}{*}{ Restriction on banks own nonfin firms (recipient) } & -1.42 & -1.42 & -1.42 \\
\hline & [0.144] & [0.112] & [0.116] \\
\hline \multirow[t]{2}{*}{ capital regulatory index (source) } & 0.23 & 0.23 & 0.23 \\
\hline & [0.123] & {$[0.128]$} & {$[0.124]$} \\
\hline \multirow[t]{2}{*}{ capital regulatory index (recipient) } & -0.34 & -0.34 & -0.34 \\
\hline & {$[0.028]^{* *}$} & {$[0.025]^{* *}$} & {$[0.025]^{* *}$} \\
\hline \multirow[t]{2}{*}{ strength of external audit (source) } & 0.70 & 0.70 & 0.70 \\
\hline & {$[0.250]$} & {$[0.136]$} & {$[0.254]$} \\
\hline \multirow[t]{2}{*}{ strength of external audit (recipient) } & -0.65 & -0.65 & -0.65 \\
\hline & {$[0.033]^{* *}$} & {$[0.032]^{* *}$} & {$[0.030]^{* *}$} \\
\hline \multirow[t]{2}{*}{ fin statement transparency (source) } & 1.85 & 1.85 & 1.85 \\
\hline & {$[0.027]^{* *}$} & {$[0.030]^{* *}$} & {$[0.027]^{* *}$} \\
\hline \multirow[t]{2}{*}{ fin statement transparency (recipient) } & -0.56 & -0.56 & -0.56 \\
\hline & {$[0.059]^{*}$} & {$[0.047]^{* *}$} & {$[0.055]^{*}$} \\
\hline \multirow[t]{2}{*}{ Independence of Supervisory Authority (source) } & 1.05 & 1.05 & 1.05 \\
\hline & {$[0.461]$} & [0.462] & [0.423] \\
\hline \multirow[t]{2}{*}{ Independence of Supervisory Authority (recipient) } & -0.83 & -0.83 & -0.83 \\
\hline & {$[0.031]^{* *}$} & {$[0.022]^{* *}$} & {$[0.024]^{* *}$} \\
\hline \multirow[t]{2}{*}{ Official Supervisory Power (source) } & 0.66 & 0.66 & 0.66 \\
\hline & {$[0.078]^{*}$} & {$[0.072]^{*}$} & {$[0.074]^{*}$} \\
\hline \multirow[t]{2}{*}{ Official Supervisory Power (recipient) } & -0.52 & -0.52 & -0.52 \\
\hline & {$[0.023]^{* *}$} & {$[0.023]^{* *}$} & {$[0.024]^{* *}$} \\
\hline \multirow[t]{2}{*}{ Loan classification leniency (source) } & -0.27 & -0.27 & -0.27 \\
\hline & {$[0.020]^{* *}$} & {$[0.011]^{* *}$} & {$[0.015]^{* *}$} \\
\hline \multirow[t]{2}{*}{ Loan classification leniency (recipient) } & 0.41 & 0.41 & 0.41 \\
\hline & {$[0.036]^{* *}$} & {$[0.033]^{* *}$} & {$[0.033]^{* *}$} \\
\hline \multirow[t]{2}{*}{ Creditor rights (source) } & -2.40 & -2.40 & -2.40 \\
\hline & {$[0.018]^{* *}$} & {$[0.012]^{* *}$} & {$[0.019]^{* *}$} \\
\hline \multirow[t]{2}{*}{ Creditor rights (recipient) } & 3.65 & 3.65 & 3.65 \\
\hline & {$[0.026]^{* *}$} & {$[0.032]^{* *}$} & {$[0.037]^{* *}$} \\
\hline \multirow[t]{2}{*}{ Info sharing (source) } & -0.68 & -0.68 & -0.68 \\
\hline & {$[0.035]^{* *}$} & {$[0.042]^{* *}$} & {$[0.034]^{* *}$} \\
\hline \multirow[t]{2}{*}{ Info sharing (recipient) } & 1.17 & 1.17 & 1.17 \\
\hline & {$[0.084]^{*}$} & {$[0.083]^{*}$} & {$[0.084]^{*}$} \\
\hline \multirow[t]{2}{*}{ No. of days to enforce contracts (recipient) } & 0.10 & 0.10 & 0.10 \\
\hline & {$[0.036]^{* *}$} & {$[0.082]^{*}$} & {$[0.038]^{* *}$} \\
\hline \multirow[t]{2}{*}{ No. of days to enforce contracts (source) } & -0.15 & -0.15 & -0.15 \\
\hline & {$[0.027]^{* *}$} & {$[0.023]^{* *}$} & {$[0.025]^{* *}$} \\
\hline
\end{tabular}


Top 5 bank concentration (recipient)

Government bank ownership (recipient)

Property rights (source)

Property rights (recipient)

Log income (source)

Log income (recipient)

Log population (source)

Log population (recipient)

Common language

Log distance

Fin liberalization (source)

Fin liberalization (recipient)

Growth opportunity (source)

Growth opportunity (recipient)

Source country fixed effect

Recipient country fixed effect

Time fixed effect

Observations

No. of source countries

No. of recipient countries

Adj. R-squared

\section{$-3.64$ \\ [0.069]*}

$-1.67$

[0.030]**

$-2.44$

$[0.034]^{* *}$

1.86

[0.029]**

$-1.16$

[0.364]

2.11

[0.112]

1.60

[0.120]

2.48

[0.051]*

5.40

$[0.007]^{* * *}$

$-1.38$

[0.277]

0.37

[0.193]

0.52

[0.012]**

$-1.22$

[0.029]**

1.67

$[0.030]^{* *}$

yes

yes

yes

7,923

23

70

0.19
$-3.64$

[0.051]*

$-1.67$

[0.024]**

$-2.44$

[0.036]**

1.86

[0.025]**

$-1.16$

[0.365]

2.11

[0.081]*

1.60

[0.288]

2.48

[0.033]**

5.40

[0.013]**

$-1.38$

[0.128]

0.37

[0.341]

0.52

[0.007]***

$-1.22$

[0.022]**

1.67

[0.028]**

yes

yes

yes

7,923

23

70

0.19
$-3.64$

[0.054]*

$-1.67$

[0.023]**

$-2.44$

[0.033]**

1.86

[0.026]**

$-1.16$

[0.388]

2.11

[0.101]

1.60

[0.135]

2.48

[0.035]**

5.40

[0.006]***

$-1.38$

[0.218]

0.37

[0.197]

0.52

[0.009]***

$-1.22$

[0.030]**

1.67

[0.029]**

yes

yes

yes

7,923

23

70

0.19

Note: This table presents robustness tests for equation 7 in Table 4 of the main text under different two-way clustering specifications for standard errors of coefficients indicated in the first row (Petersen 2009). The dependent variable is bank flows, which is defined as 100 times the log-difference of total foreign claims (FCsr) from source country $s$ to recipient country $r$, that is, $100 * \Delta \ln (F C s r)$. P-values are computed by the heteroskedasticity-robust standard errors clustered under different specifications and are presented in brackets. The country level banking regulatory variables are time varying and are based on three major surveys spanning almost over a decade by the World Bank (Barth, Caprio, and Levine, 2008). The values of regulatory variables for the period of 1996 to 1999 are taken from the first survey recorded in 1998/1999. Their values for the period of 2000 to 2003 are taken from the second survey that assesses the state of regulation as of the end of 2002. Their values for the period of 2004 to 2005 are taken from the third survey that was sought a characterization of the environment as of the end of 2005. Detailed variable definitions can be found in Table 1. Time fixed effects, as well as source and recipient country specific effects are included in the regressions but not reported. *, **, *** represent statistical significance at the $10 \%, 5 \%$ and $1 \%$ level respectively. 


\section{Internet Appendix Table 3: Regulatory Gaps and International Bank Flows}

Estimation: As a robustness test, we calculate the regulatory gaps between each source and recipient country, and use these as alternative explanatory variables. Specifically, we estimate the following model:

$$
\begin{aligned}
& \text { Bank } \text { Flow }_{s, r, t}=\alpha_{0}+\alpha \text { Reg Gap }_{s, r, t}+\beta \text { Institutional Gap }_{s, r, t}+\gamma \Delta X_{s, r, t} \\
& \quad+\theta_{1} \ln \left(\text { Distance }_{s, r}\right)+\theta_{2} \text { Common Language }_{s, r}+\eta_{s}+\varphi_{r}+\mu_{t}+\varepsilon_{s, r, t}
\end{aligned}
$$

where, $\quad \Delta X_{s, r, t}=X_{s, t}-X_{r, t}, \quad$ (2)

$\operatorname{Reg~Gap~}_{s, r, t}=$ Regulation $_{s, t}-$ Regulation $_{r, t}$

Institutional Gap $_{s, r, t}=$ Institutional Quality $_{s, t}-$ Institutional Quality $_{r, t}$

\begin{tabular}{|c|c|c|c|c|c|c|}
\hline & 1 & 2 & 3 & 4 & 5 & 6 \\
\hline Overall activities restrictions (gap) & $\begin{array}{l}0.38 \\
{[0.033]^{* *}}\end{array}$ & & & & $\begin{array}{l}0.50 \\
{[0.023]^{* *}}\end{array}$ & $\begin{array}{l}0.57 \\
{[0.018]^{* *}}\end{array}$ \\
\hline Restriction on banks own nonfin firms (gap) & $\begin{array}{l}0.48 \\
{[0.017]^{* *}}\end{array}$ & & & & $\begin{array}{l}0.50 \\
{[0.011]^{* *}}\end{array}$ & $\begin{array}{l}0.36 \\
{[0.014]^{* *}}\end{array}$ \\
\hline capital regulatory index (gap) & & $\begin{array}{l}0.89 \\
{[0.067]^{*}}\end{array}$ & & & $\begin{array}{l}0.75 \\
{[0.032]^{* *}}\end{array}$ & $\begin{array}{l}0.85 \\
{[0.035]^{* *}}\end{array}$ \\
\hline strength of external audit (gap) & & & $\begin{array}{l}0.46 \\
{[0.017]^{* *}}\end{array}$ & & $\begin{array}{l}0.35 \\
{[0.066]^{*}}\end{array}$ & $\begin{array}{l}0.36 \\
{[0.077]^{*}}\end{array}$ \\
\hline fin statement transparency (gap) & & & $\begin{array}{l}0.81 \\
{[0.031]^{* *}}\end{array}$ & & $\begin{array}{l}0.78 \\
{[0.033]^{* *}}\end{array}$ & $\begin{array}{l}0.92 \\
{[0.028]^{* *}}\end{array}$ \\
\hline $\begin{array}{l}\text { Independence of Supervisory Authority - } \\
\text { Overall (gap) }\end{array}$ & & & & $\begin{array}{l}0.92 \\
{[0.033]^{* *}}\end{array}$ & $\begin{array}{l}0.58 \\
{[0.047]^{* *}}\end{array}$ & $\begin{array}{l}0.63 \\
{[0.032]^{* *}}\end{array}$ \\
\hline Official Supervisory Power (gap) & & & & $\begin{array}{l}0.29 \\
{[0.033]^{* *}}\end{array}$ & $\begin{array}{l}0.30 \\
{[0.034]^{* *}}\end{array}$ & $\begin{array}{l}0.24 \\
{[0.044]^{* *}}\end{array}$ \\
\hline Loan classification leniency (gap) & & & & & $\begin{array}{l}-0.51 \\
{[0.029]^{* *}}\end{array}$ & $\begin{array}{l}-0.67 \\
{[0.025]^{* *}}\end{array}$ \\
\hline Creditor rights (gap) & -4.53 & -4.46 & -4.37 & -4.28 & -4.41 & -5.36 \\
\hline Info share (gap) & $\begin{array}{l}{[0.046]^{* *}} \\
-1.14 \\
{[0.024]^{* *}}\end{array}$ & $\begin{array}{l}{[0.012]^{* *}} \\
-1.12 \\
{[0.065]^{*}}\end{array}$ & $\begin{array}{l}{[0.006]^{* * *}} \\
-1.14 \\
{[0.026]^{* *}}\end{array}$ & $\begin{array}{l}{[0.004]^{* * *}} \\
-1.11 \\
{[0.027]^{* *}}\end{array}$ & $\begin{array}{l}{[0.004]^{* * *}} \\
-1.19 \\
{[0.023]^{* *}}\end{array}$ & $\begin{array}{l}{[0.003]^{* * *}} \\
-1.48 \\
{[0.040]^{* *}}\end{array}$ \\
\hline Property rights (gap) & $\begin{array}{l}-1.67 \\
{[0.064]^{*}}\end{array}$ & $\begin{array}{l}-1.83 \\
{[0.062]^{*}}\end{array}$ & $\begin{array}{l}-1.93 \\
{[0.053]^{*}}\end{array}$ & $\begin{array}{l}-2.11 \\
{[0.028]^{* *}}\end{array}$ & $\begin{array}{l}-1.60 \\
{[0.039]^{* *}}\end{array}$ & $\begin{array}{l}-1.74 \\
{[0.043]^{* *}}\end{array}$ \\
\hline Fin liberalization (gap) & & & & & & $\begin{array}{l}0.49 \\
{[0.189]}\end{array}$ \\
\hline Growth opportunity (gap) & & & & & & $\begin{array}{l}-1.46 \\
{[0.038]^{* *}}\end{array}$ \\
\hline Sample period & & & 1996-2007 & & & $1996-2005$ \\
\hline Other control variables & yes & yes & yes & yes & yes & yes \\
\hline Source country fixed effect & yes & yes & yes & yes & yes & yes \\
\hline Recipient country fixed effect & yes & yes & yes & yes & yes & yes \\
\hline Time fixed effect & yes & yes & yes & yes & yes & yes \\
\hline Observations & 13,738 & 13,790 & 13,467 & 13,601 & 12,936 & 7,923 \\
\hline No. of source countries & 26 & 26 & 26 & 26 & 26 & 23 \\
\hline No. of recipient countries & 111 & 111 & 108 & 109 & 102 & 70 \\
\hline Adj. R-squared & 0.24 & 0.23 & 0.21 & 0.22 & 0.24 & 0.22 \\
\hline
\end{tabular}
$s$ and $r$ indicate the source and recipient country, respectively, and $t$ indicates time (year).

Note: The dependent variable is bank flows, which is defined as 100 times the log-difference of the total foreign claims (FCsr) from source country $s$ to recipient country $r$, that is, $100^{*} \Delta \ln (F C s r)$. P-values are computed by the heteroskedasticity-robust standard errors clustered for recipient countries and are presented in brackets. *, $* *, * * *$ represent statistical significance at the $10 \%, 5 \%$ and $1 \%$ level respectively. 


\section{Internet Appendix Table 4: Change Regressions}

Estimation: We examine the effects of regulatory changes on international bank flow changes. Focusing on changes allows us to account for unobservable time-invariant country specific characteristics that might influence both the level of bank regulation and international bank flows. This approach also helps alleviate the endogeneity concern (Lin et al., 2011).

The first differencing estimation relates to the time periods corresponding to the three surveys. Specifically, we examine how changes in the regulatory gap (between the source and recipient pairs) influence changes in bank flows. Instead of using the full ten years of data, we focus on the three survey years $(1999,2002,2005)$ to measure the regulatory changes. To capture the potential lagged effects of regulatory changes, we use bank flow data in years 2001, 2004, and 2007 data to measure the changes in bank flows. The sample thus contains observations of two time series changes. The countries without regulatory changes are dropped from the estimation and the sample size drops to about 1730. Specifically, the estimation can be expressed as follows:

\begin{tabular}{|c|c|c|c|c|c|c|}
\hline & 1 & 2 & 3 & 4 & 5 & 6 \\
\hline$\Delta$ Overall activities restrictions (gap) & $\begin{array}{l}0.46 \\
{[0.031]^{* *}}\end{array}$ & & & & $\begin{array}{l}0.43 \\
{[0.035]^{* *}}\end{array}$ & $\begin{array}{l}0.51 \\
{[0.031]^{* *}}\end{array}$ \\
\hline$\Delta$ Restriction on banks own nonfin firms (gap) & $\begin{array}{l}0.75 \\
{[0.045]^{* *}}\end{array}$ & & & & $\begin{array}{l}0.62 \\
{[0.041]^{* *}}\end{array}$ & $\begin{array}{l}0.48 \\
{[0.053]^{*}}\end{array}$ \\
\hline$\Delta$ capital regulatory index (gap) & & $\begin{array}{l}3.68 \\
{[0.015]^{* *}}\end{array}$ & & & $\begin{array}{l}3.53 \\
{[0.018]^{* *}}\end{array}$ & $\begin{array}{l}3.24 \\
{[0.016]^{* *}}\end{array}$ \\
\hline$\Delta$ strength of external audit (gap) & & & $\begin{array}{l}0.98 \\
{[0.034]^{* *}}\end{array}$ & & $\begin{array}{l}0.81 \\
{[0.039]^{* *}}\end{array}$ & $\begin{array}{l}0.59 \\
{[0.047]^{* *}}\end{array}$ \\
\hline$\Delta$ fin statement transparency (gap) & & & $\begin{array}{l}1.12 \\
{[0.029]^{* *}}\end{array}$ & & $\begin{array}{l}1.10 \\
{[0.037]^{* *}}\end{array}$ & $\begin{array}{l}1.15 \\
{[0.052]^{*}}\end{array}$ \\
\hline $\begin{array}{l}\Delta \text { Independence of Supervisory Authority - Overall } \\
\text { (gap) }\end{array}$ & & & & $\begin{array}{l}2.78 \\
{[0.060] *}\end{array}$ & $\begin{array}{l}2.81 \\
{[0.062]^{*}}\end{array}$ & $\begin{array}{l}3.00 \\
{[0.059]^{*}}\end{array}$ \\
\hline$\triangle$ Official Supervisory Power (gap) & & & & $\begin{array}{l}0.15 \\
{[0.022]^{* *}}\end{array}$ & $\begin{array}{l}0.34 \\
{[0.016]^{* *}}\end{array}$ & $\begin{array}{l}0.46 \\
{[0.015]^{* *}}\end{array}$ \\
\hline$\Delta$ Loan classification leniency (gap) & & & & & $\begin{array}{l}-0.36 \\
{[0.028] * *}\end{array}$ & $\begin{array}{l}-0.47 \\
{[0.016]^{* *}}\end{array}$ \\
\hline$\Delta$ Creditor rights (gap) & $\begin{array}{l}-3.08 \\
{[0.013]^{* *}}\end{array}$ & $\begin{array}{l}-3.14 \\
{[0.019]^{* *}}\end{array}$ & $\begin{array}{l}-3.02 \\
{[0.075]^{*}}\end{array}$ & $\begin{array}{l}-3.27 \\
{[0.020]^{* *}}\end{array}$ & $\begin{array}{l}-2.81 \\
{[0.026]^{* *}}\end{array}$ & $\begin{array}{l}-3.52 \\
{[0.020]^{* *}}\end{array}$ \\
\hline$\Delta$ Info share (gap) & $\begin{array}{l}-1.82 \\
{[0.034]^{* *}}\end{array}$ & $\begin{array}{l}-2.04 \\
{[0.026]^{* *}}\end{array}$ & $\begin{array}{l}-1.51 \\
{[0.040]^{* *}}\end{array}$ & $\begin{array}{l}-2.42 \\
{[0.018]^{* *}}\end{array}$ & $\begin{array}{l}-1.63 \\
{[0.039] * *}\end{array}$ & $\begin{array}{l}-1.49 \\
{[0.052]^{*}}\end{array}$ \\
\hline$\Delta$ Property rights (gap) & $\begin{array}{l}-2.09 \\
{[0.130]}\end{array}$ & $\begin{array}{l}-2.06 \\
{[0.039]^{* *}}\end{array}$ & $\begin{array}{l}-2.23 \\
{[0.053]^{*}}\end{array}$ & $\begin{array}{l}-2.06 \\
{[0.044]^{* *}}\end{array}$ & $\begin{array}{l}-2.11 \\
{[0.038]^{* *}}\end{array}$ & $\begin{array}{l}-1.53 \\
{[0.047]^{* *}}\end{array}$ \\
\hline$\Delta \log$ income (gap) & $\begin{array}{l}-2.73 \\
{[0.038]^{* *}}\end{array}$ & $\begin{array}{l}-2.73 \\
{[0.046]^{* *}}\end{array}$ & $\begin{array}{l}-2.82 \\
{[0.201]}\end{array}$ & $\begin{array}{l}-2.60 \\
{[0.083]^{*}}\end{array}$ & $\begin{array}{l}-2.73 \\
{[0.075]^{*}}\end{array}$ & $\begin{array}{l}-3.14 \\
{[0.063]^{*}}\end{array}$ \\
\hline$\Delta$ Log population (gap) & $\begin{array}{l}3.65 \\
{[0.143]}\end{array}$ & $\begin{array}{l}3.28 \\
{[0.230]}\end{array}$ & $\begin{array}{l}4.50 \\
{[0.111]}\end{array}$ & $\begin{array}{l}3.74 \\
{[0.064]^{*}}\end{array}$ & $\begin{array}{l}4.41 \\
{[0.062]^{*}}\end{array}$ & $\begin{array}{l}5.31 \\
{[0.036]^{* *}}\end{array}$ \\
\hline$\Delta$ Fin liberalization (gap) & & & & & & $\begin{array}{l}0.15 \\
{[0.347]}\end{array}$ \\
\hline$\triangle$ Growth opportunity (gap) & & & & & & $\begin{array}{l}-0.34 \\
{[0.039]^{* *}}\end{array}$ \\
\hline Observations & 1,731 & 1,701 & 1,673 & 1,673 & 1,639 & 1,081 \\
\hline Adj. R-squared & 0.19 & 0.16 & 0.16 & 0.17 & 0.14 & 0.18 \\
\hline
\end{tabular}

Note: The regressions examine the effects of the changes of regulatory and institutional gaps on changes of bank inflows. The dependent variable is the difference of bank flows between 2001 and 2004 and that between 2004 and 2007, i.e., $\Delta y_{t}, t=2007$ and 2004, where $y$ is the bank flows defined as 100 times the log-difference of the ratio of total foreign claims (FCsr) from source country $s$ to recipient country $r$, that is, $100 * \Delta \ln (F C s r)$. All explanatory variables are lagged two years changes in regulation gaps between source and recipient countries (i.e. difference of regulatory gaps between 1999 and 2002 and that between 2002 and 2005). P-values are computed by the heteroskedasticity-robust standard errors clustered for recipient countries and are presented in brackets. $\quad *, * *, * * *$ represent statistical significance at the $10 \%, 5 \%$ and $1 \%$ level respectively. 


\section{Internet Appendix Table 5: The current account analysis}

Estimation: Here we follow the traditional intertemporal approach to the current account (see, for example, a survey by Obstfeld and Rogoff (1995) on this research). It has been developed to address the Feldstein and Horioka (1980) saving-investment paradox of home bias in real investment (Sachs (1981)), and is related current "global savings glut" debate. We adopt a parsimonious version of this model documented in Tesar (1991) and Kraay and Ventura (2002).

The traditional regression model is given as follows: (6)

$$
\mathrm{CA}_{\mathrm{it}}=\alpha_{0}+\alpha \mathrm{S}_{\mathrm{it}}+\mathrm{u}_{\mathrm{it}}
$$

where $\mathrm{CA}_{\text {it }}$ and $\mathrm{S}_{\text {it }}$ are the current account/GNP and gross saving/GNP of country i respectively, $\alpha_{0}$ and $\alpha$ are parameters, and $u_{i t}$ is residual. The parameters $\alpha$ provides a measure of the response of the current account to the changes in saving, which in turn, implies the amount of capital outflow from the country. We augment this simple model of the determinants of current account by a full set of key regulatory variables and other controls from our bank flow model as follows:

$$
\mathrm{CA}_{\mathrm{it}}=\alpha_{0}+\alpha \mathrm{S}_{\mathrm{it}}+\beta \text { Regulation }_{\mathrm{it}}+\gamma \text { Control }_{\mathrm{it}}+\mathrm{u}_{\mathrm{it}}
$$

where Regulation $_{\text {it }}$ and Control $_{\text {it }}$ are, respectively, a vector of regulatory variables and a vector of

\begin{tabular}{|c|c|c|c|c|c|c|c|}
\hline & 1 & 2 & 3 & 4 & 5 & 6 & 7 \\
\hline \multirow[t]{2}{*}{ Saving/GNP (\%) (source) } & 0.79 & 0.78 & 0.64 & 0.75 & 0.82 & 0.73 & 0.72 \\
\hline & {$[0.006]^{* * *}$} & {$[0.003]^{* * *}$} & {$[0.003]^{* * *}$} & {$[0.005]^{* * *}$} & {$[0.009]^{* * *}$} & {$[0.005]^{* * *}$} & {$[0.004]^{* * *}$} \\
\hline \multirow[t]{2}{*}{ Overall activities restrictions (source) } & & 0.30 & & & & 0.49 & 0.58 \\
\hline & & {$[0.016]^{* *}$} & & & & {$[0.031]^{* *}$} & {$[0.026]^{* *}$} \\
\hline \multicolumn{8}{|l|}{ Restriction on banks own nonfin firms } \\
\hline \multirow[t]{2}{*}{ (source) } & & 1.41 & & & & 1.31 & 1.16 \\
\hline & & {$[0.078]^{*}$} & & & & {$[0.014]^{* *}$} & {$[0.008]^{* * *}$} \\
\hline \multirow[t]{2}{*}{ capital regulatory index (source) } & & & 0.25 & & & 0.35 & 0.57 \\
\hline & & & {$[0.035]^{* *}$} & & & {$[0.126]$} & {$[0.072]^{*}$} \\
\hline \multirow[t]{2}{*}{ strength of external audit (source) } & & & & 0.74 & & 0.63 & 1.15 \\
\hline & & & & {$[0.034]^{* *}$} & & [0.243] & {$[0.121]$} \\
\hline \multirow[t]{2}{*}{ fin statement transparency (source) } & & & & 1.48 & & 1.56 & 1.53 \\
\hline & & & & {$[0.018]^{* *}$} & & {$[0.023]^{* *}$} & {$[0.019]^{* *}$} \\
\hline \multicolumn{8}{|l|}{ Independence of Supervisory Authority } \\
\hline \multirow[t]{2}{*}{ (source) } & & & & & 0.53 & 0.71 & 0.96 \\
\hline & & & & & {$[0.092]^{*}$} & [0.605] & {$[0.454]$} \\
\hline \multirow[t]{2}{*}{ Official Supervisory Power (source) } & & & & & 0.96 & 0.91 & 0.81 \\
\hline & & & & & {$[0.160]$} & {$[0.057]^{*}$} & {$[0.028]^{* *}$} \\
\hline \multirow[t]{2}{*}{ Loan classification leniency (source) } & & & & & & -0.50 & -0.36 \\
\hline & & & & & & {$[0.015]^{* *}$} & {$[0.016]^{* *}$} \\
\hline \multirow[t]{2}{*}{ Creditor rights (source) } & & -3.32 & -2.83 & -2.55 & -2.50 & -2.47 & -2.44 \\
\hline & & {$[0.025]^{* *}$} & {$[0.154]$} & {$[0.061]^{*}$} & [0.137] & {$[0.032]^{* *}$} & {$[0.041]^{* *}$} \\
\hline \multirow[t]{2}{*}{ Info sharing (source) } & & -1.73 & -2.30 & -1.56 & -1.32 & -1.13 & -1.44 \\
\hline & & {$[0.026]^{* *}$} & {$[0.017]^{* *}$} & {$[0.019]^{* *}$} & [0.113] & {$[0.004]^{* * *}$} & {$[0.017]^{* *}$} \\
\hline \multirow[t]{2}{*}{ No. of days to enforce contracts (source) } & & & & & & 0.18 & 0.17 \\
\hline & & & & & & {$[0.015]^{* *}$} & {$[0.023]^{* *}$} \\
\hline \multirow[t]{2}{*}{ Property rights (source) } & & -3.68 & -4.90 & -3.77 & -3.98 & -4.13 & -4.51 \\
\hline & & {$[0.065]^{*}$} & {$[0.044]^{* *}$} & {$[0.072]^{*}$} & {$[0.062]^{*}$} & {$[0.037]^{* *}$} & {$[0.021]^{* *}$} \\
\hline
\end{tabular}
other control variables used in the previous bank flow analysis. 


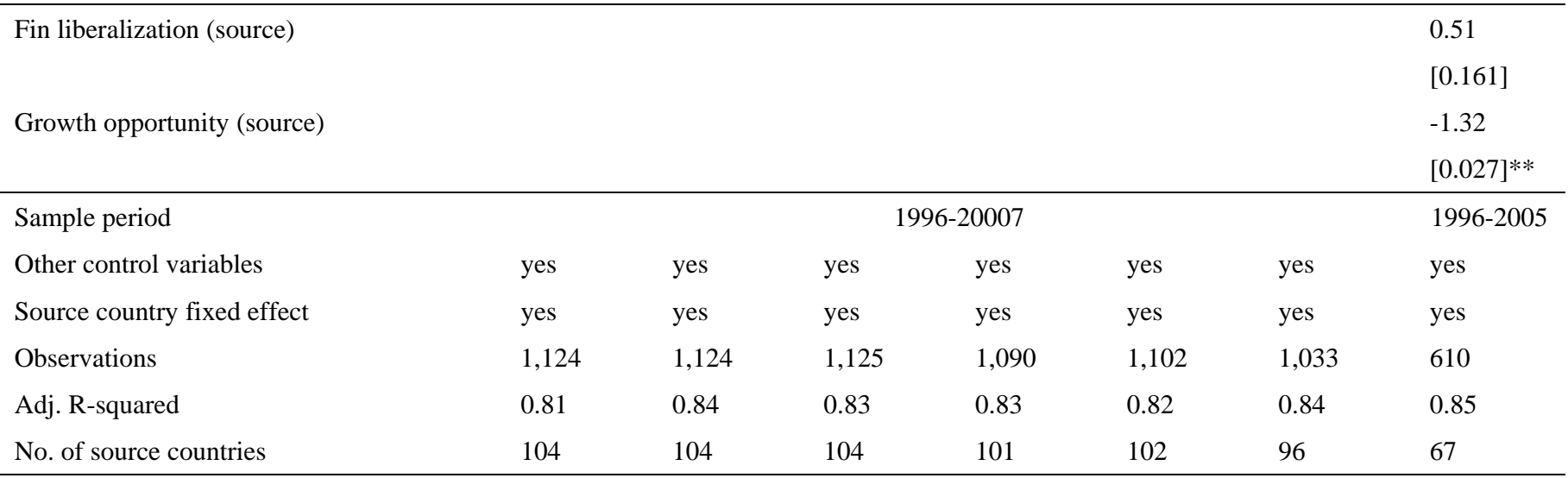

Note: The dependent variable is the current account/GNP (in \%), which is a proxy for aggregate capital outflows from the source countries in the sample. The country level banking regulatory variables are time varying and are based on three major surveys spanning almost over a decade by the World Bank. Detailed variable definitions can be found in Table 1. Other control variables include log income (source) and log population (source). Time fixed effects and source country specific effects are included in the regressions but not reported. P-values are computed by the heteroskedasticity-robust standard errors clustered for source countries and are presented in brackets. *, **, *** represent statistical significance at the $10 \%, 5 \%$ and $1 \%$ level respectively. 
Internet Appendix Table 6: Difference of number of foreign subsidiaries in highly regulated versus low regulation countries

\begin{tabular}{|l|l|l|l|l|l|l|}
\hline Cell & & \multicolumn{1}{|c|}{1} & \multicolumn{1}{|c|}{2} & \multicolumn{1}{|c|}{5} \\
\hline 1 & Bank size below median \& low profitability & $\begin{array}{c}\text { High } \\
\text { regulation } \\
\text { countries }\end{array}$ & $\begin{array}{c}\text { No. of } \\
\text { obs }\end{array}$ & $\begin{array}{c}\text { Low } \\
\text { regulation } \\
\text { countries }\end{array}$ & $\begin{array}{c}\text { No. } \\
\text { of } \\
\text { obs }\end{array}$ & $\begin{array}{c}\text { Difference } \\
=(1)-(3)\end{array}$ \\
\hline 2 & Bank size below median \& high profitability & 3.68 & 23 & 1.26 & 42 & 0.05 \\
\hline 3 & Bank size above median \& low profitability & 8.74 & 36 & 6.13 & 49 & $1.71^{*}$ \\
\hline 4 & Bank size above median \& high profitability & 9.41 & 34 & 6.25 & 32 & $3.16^{* *}$ \\
\hline
\end{tabular}

Note: This table test the difference of number of foreign subsidiaries in highly regulated versus low regulation countries according to the size and profitability of the banks. Bank size is measured by total assets and profitability is measured by net income divided by total assets. Both are three-year averages. ${ }^{*}, * *, * * *$ represent statistical significance at the $10 \%, 5 \%$ and $1 \%$ level respectively.

For the matching estimation:

1) For each of the 26 source countries, we create dummy variable related to each of the eight supervision and regulation measures used in our previous analysis. For each dummy variable, we assigned a value of 1 to countries which have a more stringent regulation relative to the sample median. We then construct the overall regulation index as the sum of these eight dummy variables. Thus, this overall measure ranges from 0 to 8 with a higher value indicating a higher level of bank regulation. We divide 26 source countries into two groups of high/low regulation according to the overall regulation index of each country being above or below the medium level of the index.

2) divide 26 source countries into two groups of high/low regulation according to the overall regulation index of each country being above or below the medium level of the index.

3) divide all 301 banks from the 26 source countries into big/small banks according to their size and high/low profitable banks according to their profitability in comparison to the respective medians. This gives us a total of 4 cells.

4) For the 4 cells, conduct four t-tests to see within each cell if banks located in highly regulated countries have more oversea subsidiaries than banks located in less regulated countries. 